\title{
Near Net Shape Manufacturing of Metal - A review of Approaches and their Evolutions
}

\author{
D. Marini ${ }^{1, a^{*}}, \mathrm{D}$. Cunningham ${ }^{2, \mathrm{~b}}$ and J.R. Corney ${ }^{3, \mathrm{c}}$ \\ 1, 2, 3 Department of Design, Manufacture and Engineering Management (DMEM), University of Strathclyde, \\ Montrose Street, Glasgow, UK. *Corresponding author. \\ a daniele.marini@strath.ac.uk, ${ }^{\mathrm{b}}$ dave.cunningham@strath.ac.uk, ${ }^{\mathrm{c}}$ Jonathan.Corney@strath.ac.uk.
}

\begin{abstract}
In the last thirty years the concept of manufacturability has been applied to many different processes in numerous industries. This has resulted in the emergence of several different "Design for Manufacturing" methodologies which have in common the aim of reducing productions costs through the application of general manufacturing rules. Near net shape technologies have expanded these concepts, targeting mainly primary shaping process, such as casting or forging. The desired outcomes of manufacturability analysis for near-net-shape (NNS) processes are cost and lead/time reduction through minimization of process steps (in particular cutting and finishing operations) and raw material saving. Product quality improvement, variability reduction and component design functionality enhancement are also achievable through NNS optimization.

Process parameters, product design and material selection are the changing variables in a manufacturing chain that interact in complex, non-linear ways. Consequently modeling and simulation play important roles in the investigation of alternative approaches. However defining the manufacturing capability of different processes is also a "moving target" because the various NNS technologies are constantly improving and evolving so there is challenge in accurately reflecting their requirements and capabilities. In the last decade, for example, $\mathrm{CAD}, \mathrm{CNC}$ technologies and innovation in materials have impacted enormously on the development of NNS technologies. This paper reviews the different methods reported for NNS manufacturability assessment and examines how they can make an impact on cost, quality and process variability in the context of a specific production volume. The discussion identifies a lack of structured approaches, poor connection with process optimization methodologies and a lack of empirical models as gaps in the reported approaches.
\end{abstract}

\section{Keywords}

Near Net Shape, Manufacturing Review, Forming, Casting, Additive Layer Manufacturing.

\section{Introduction}

Manufacturing industry is constantly challenged to evolve in response to changing markets and social needs. Although for many years the reduction of costs was the only goal the growing demand for lower impacts on 
the environment has also started to drive manufacturing to improve processes in terms of their sustainability and waste. Consequently the social (rather than economic) demand for the efficient use of resources is emerging as a business opportunity where highly efficient operations in terms of energy and materials will also meet regulations and enable access to high value markets.

Given this context changing manufacturing methods is frequently a necessity rather than simply an opportunity to improve profits. The continuous investigation of cost reduction and production improvement technologies has led to the emergence of a generic class of manufacturing technologies known as Near Net Shape (NNS) that can be the key to lean, green enterprises.

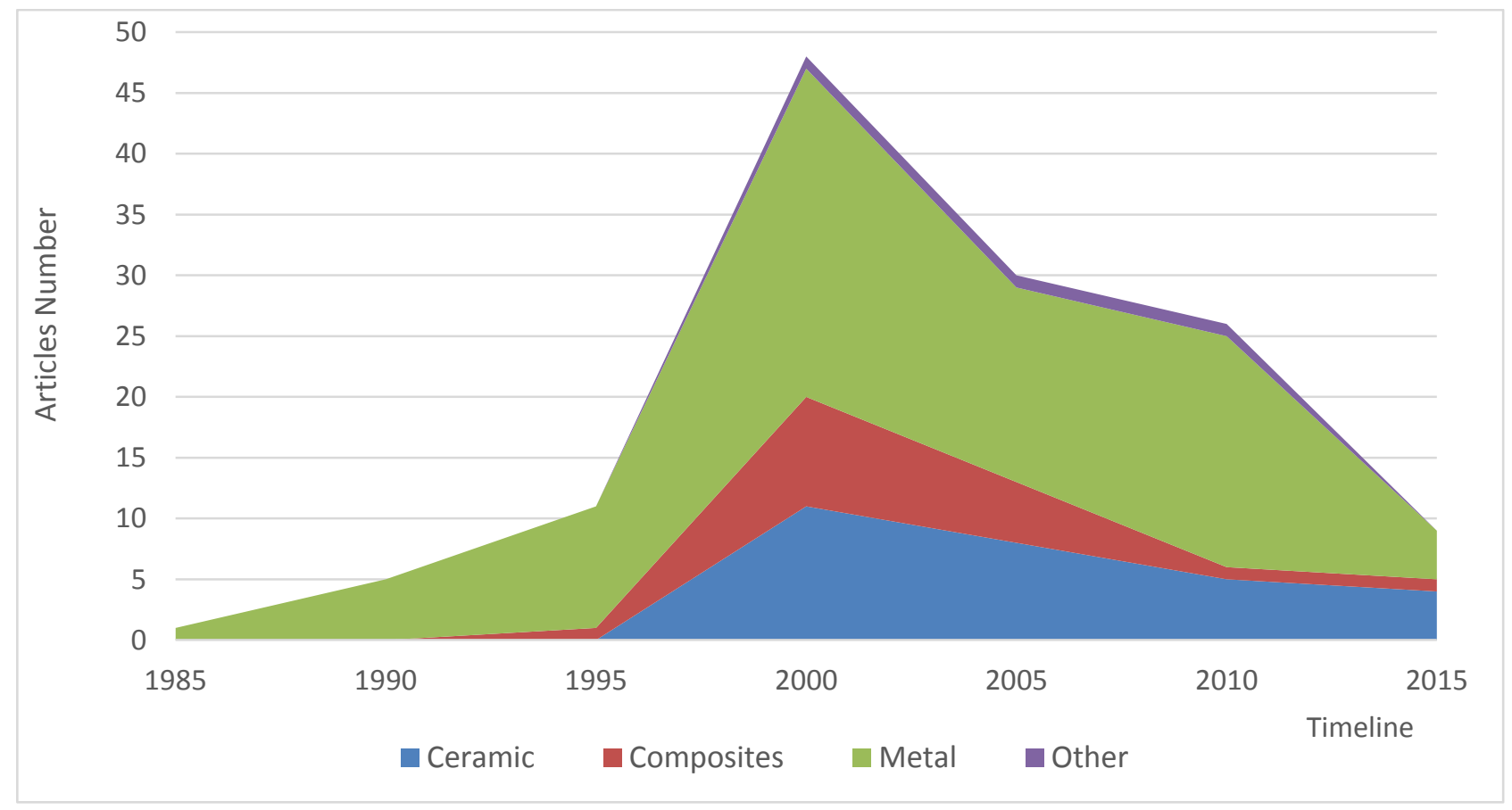

Figure 1: Annual publication volume of academic papers reporting NNS investigation classified by materials (19852015) [Table 1].

Essential NNS processes aim to create semi-finished products that are as close as possible to the desired final geometry and technological characteristics (e.g. surface finish, hardness, etc). Thus the objective of NNS is the elimination, or reduction, of finishing steps (e.g. machining operations, heat treatments, etc) and the minimization of raw material usage (e.g. reductions in scrap and wastage). NNS technologies can be seen as a component of a Lean manufacturing approach where variations in the overall manufacturing process, part design and material choices are driven by the desire to reduce waste. Indeed a virtuous circle of impacts can result from reductions in material waste for example: 
- Reduction of machining steps or the merging of several individuals components in a single part can result in a shorter process chains that both lower variability and, consequently, increased quality.

- Reductions in fabrication and assembly operations reduce the opportunity for errors and so results in lower scrappage rates.

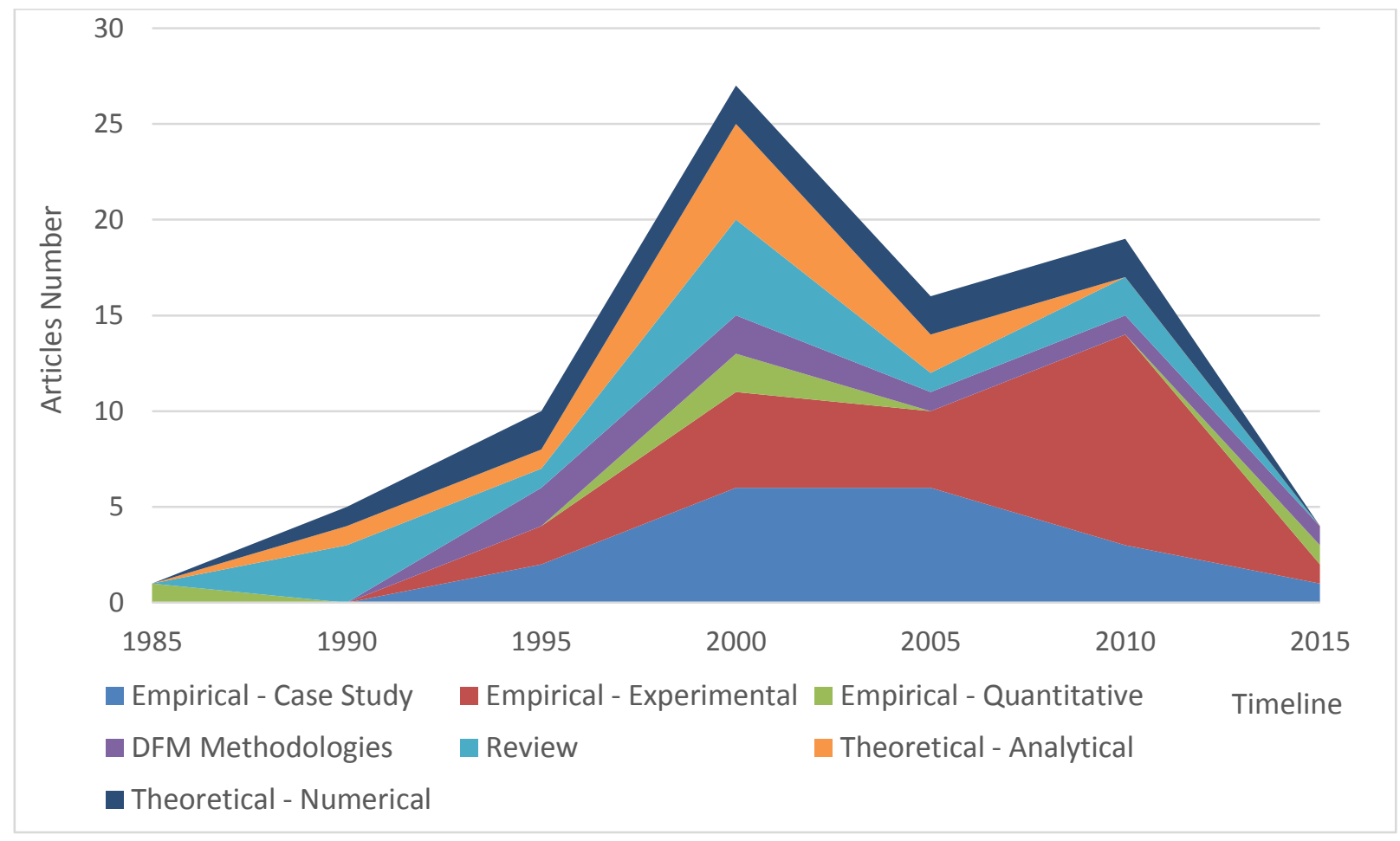

Figure 2: Annual publication volume of academic papers reporting NNS investigation categorized by research method (1985-2015) [Table 1].

In other words it is clear to any manufacturing engineer that the reduction of lead-times and waste through appropriate technologies produce many collateral advantages beyond the basic savings. NNS as a distinct subject has its roots in the "Design for Manufacturing" (DFM) work of Boothroyd and Dewurst [1] in the 1980s. Their pioneering work on a systematic approach to "Design For Assembly" (DFA), directly influenced subsequent approaches to the improvement of process efficiency. For example Ishii et al. [2] developed a 'Design For Injection Molding' (DFIM) system which was directly implemented in CAD system. The knowledge based system was able to screen drawings associated with mechanical components and apply DFIM rules to make suggestions to tailor their shapes for injection molding. Many other authors have reported the implementation of similar DFM codes in CAD/CAE system. Following Tateno [3], Hwang and Stoehr [4], Mathur et al. [5], Doege and Thalemann [6] and other pioneering studies, Altan and Miller [7] was the first to clearly define the aims and boundaries of NNS design. He first discusses the conceptual design stage where "A feasible part/process design is not achieved until a balance is achieved among 
functional requirements, production volume, part geometry, process capabilities, material properties, tooling requirements, equipment requirements and other factors". Many alternatives need to be explored in this phase, responding to every "what-if" question. But, he suggests, it is at the detailed design stage, 'design for manufacturability' needs to be evaluate. Altan and Miller [7] define three possible forms of manufacturability evaluation.

1) The modifications, or evolution, of a design after the specific combination of material and manufacturing of material and manufacturing process is defined.

2) The evaluation of several potential candidate process/material combinations when the component design is fixed.

3) The re-design of a part for a new manufacturing process.

However importantly the authors asserts all these scenarios can be interpreted as "requiring a process which will start with an initial representation of the design and then transform it, if necessary, into a another part which meets all of the functional requirements and can also be produced" [7]. This insight is fundament to all NNS methodologies reported in the literature surveyed by this paper surveys. The resulting summary charts the evolution of NNS concepts across the last 25 years. The overall objective is to define streams, or patterns, in the research and identify the principal and most effective approaches to the investigation of NNS processes.

Table 1: Articles searching and selection strategy

\begin{tabular}{|c|c|c|c|c|c|c|}
\hline \multirow{2}{*}{\multicolumn{2}{|c|}{$\begin{array}{l}\text { Search words } \\
\text { All fields }\end{array}$}} & \multicolumn{2}{|l|}{ Refined by } & \multirow{2}{*}{$\begin{array}{l}\text { Time } \\
\text { span }\end{array}$} & \multirow{2}{*}{$\begin{array}{l}\text { Articles } \\
\text { number }\end{array}$} & \multirow{2}{*}{$\begin{array}{l}\text { Search } \\
\text { Engine }\end{array}$} \\
\hline & & Subject Areas & Topic & & & \\
\hline \multicolumn{2}{|c|}{ Near Net Shape AND Manufacturing } & \multirow{2}{*}{$\begin{array}{l}\text { Engineering, } \\
\text { Material } \\
\text { Science, } \\
\text { Design }\end{array}$} & & \multirow[b]{2}{*}{$\begin{array}{l}\text { All } \\
\text { years }\end{array}$} & 6006 & \multirow[b]{2}{*}{$\begin{array}{l}\text { Scopus } \\
\text { (Elsevier) }\end{array}$} \\
\hline \multicolumn{2}{|c|}{ Near Net Shape AND Manufacturing } & & $\begin{array}{l}\text { Process, Process } \\
\text { Technology, Material } \\
\text { Processing, Design }\end{array}$ & & 550 & \\
\hline \multicolumn{7}{|c|}{ Keywords/Title/ Abstract $\quad$ All fields } \\
\hline Near Net Shape & Process & $\begin{array}{l}\text { Engineering, } \\
\text { Design }\end{array}$ & & \multirow{3}{*}{$\begin{array}{l}\text { All } \\
\text { years }\end{array}$} & 249 & \multirow{3}{*}{$\begin{array}{l}\text { Scopus } \\
\text { (Elsevier) }\end{array}$} \\
\hline Near Net Shape & Material & $\begin{array}{l}\text { Engineering, } \\
\text { Design }\end{array}$ & & & 269 & \\
\hline Near Net Shape & Design & $\begin{array}{l}\text { Engineering, } \\
\text { Design }\end{array}$ & & & 105 & \\
\hline \multicolumn{2}{|l|}{ Keywords/Title/ Abstract } & \multicolumn{5}{|c|}{ Refined by: Abstract Verification } \\
\hline \multirow{2}{*}{\multicolumn{2}{|c|}{$\begin{array}{l}\text { Near Net Shape AND Manufacturing } \\
\text { AND (Material OR Process OR Design) }\end{array}$}} & All fields & $\begin{array}{l}\text { Material, Design, } \\
\text { Process, Processing } \\
\text { Technology }\end{array}$ & \multirow{2}{*}{$\begin{array}{l}\text { All } \\
\text { years }\end{array}$} & 135 & \multirow{2}{*}{$\begin{array}{l}\text { Scopus } \\
\text { (Elsevier, } \\
\text { Google } \\
\text { Scholar) }\end{array}$} \\
\hline & & All fields & $\begin{array}{l}\text { Material, Design, } \\
\text { Process, Processing } \\
\text { Technology, Metal }\end{array}$ & & 82 & \\
\hline
\end{tabular}




\section{Scoping the Literature Review}

Table 1 details the searching strategies for the selection of NNS papers included in this survey. A number of different search terms and screening approach were employed. A broad search was followed by a process of abstract verification that allowed the scope to be limited to papers and articles related to metal manufacturing processes.

Figure 1 illustrates the rate and focus of NNS research reported over the last thirty years. Since the peak of NNS research activity (between 1995 and 2005) the variety of materials under investigation has dramatically increased. The cost of composites and ceramic components appears to have motivated much of this recent work. Similarly industries that use titanium, or complex metal alloys, have provided easiest justifications of NNS approaches and allowed the subsequent spread of successful applications to other, less costly, materials. Only a few NNS investigation relating to exotic materials, such as rhenium or amorphous alloys, have been published. Given the high costs of such metals it is likely that commercial confidentiality has restricted dissemination of this work.

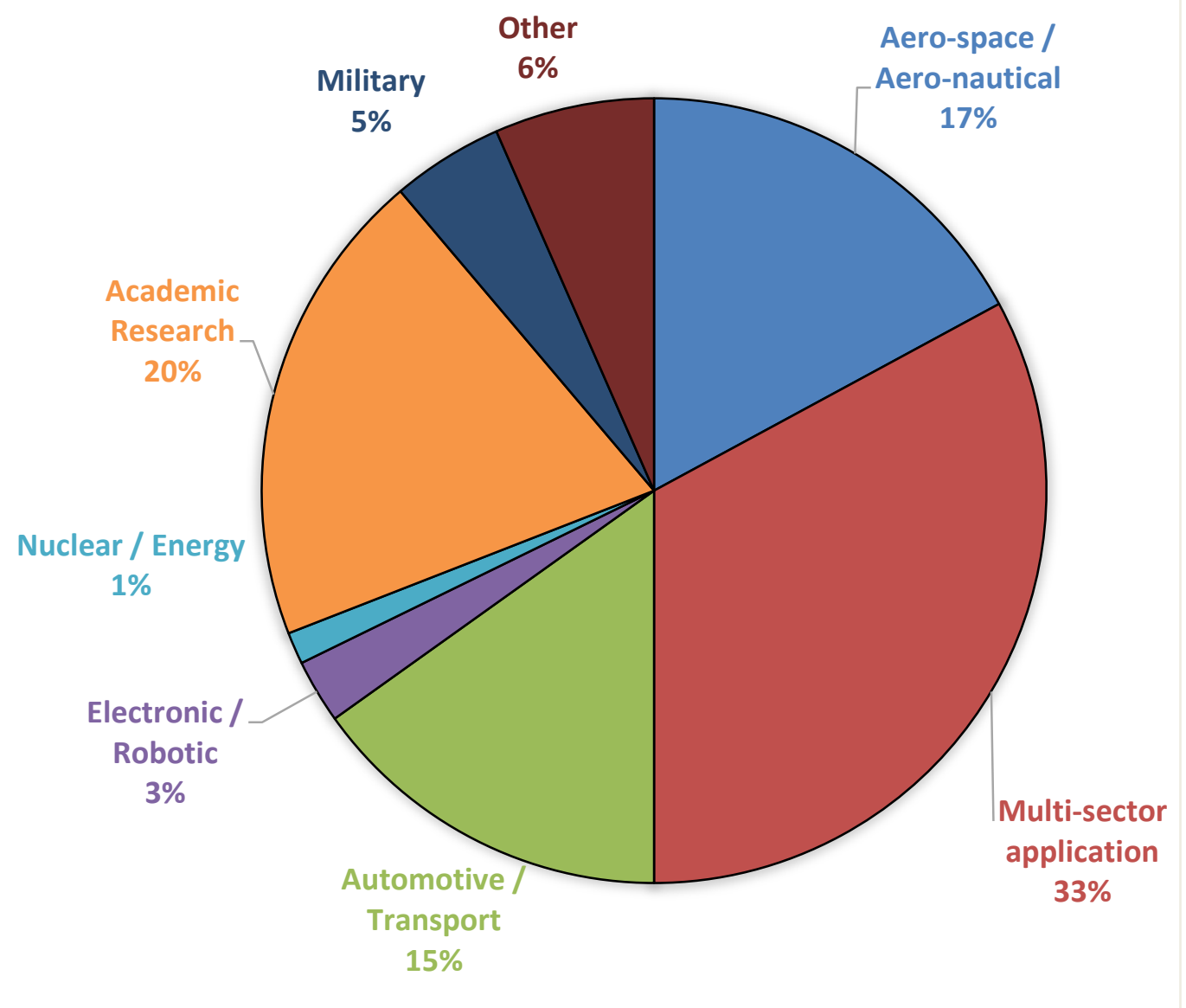

Figure 3: Papers distribution by Applications 


\section{Review Synthesis}

In this section the articles have been categorized in terms of the research methodologies applied (i.e. experimental, analytical, review meta-analysis, etc.). Figure 2 shows how the approaches adopted by researchers have varied over the years and demonstrates the predominance of the empirical approach.

Figure 3 details the distribution of papers in terms of the industry sectors: aero-space/aero-nautical, multisector application (gears, spline shaft, connecting rods, magnets production), automotive, electronic/robotic, nuclear/energy, academic research, military and others (mold fabrication, heavy industry, ingots production, ecologic productions, biomedical). Figure 4 shows the percentage of NNS papers associated specific processes: forging (hot, cold, precision, closed-die forging, including hot extrusion and indirect extrusion), forming (including flow forming, hydroforming, semi-solid metal casting, semi-solid metal extrusion, rolling and strip casting), casting (sand, investment, centrifugal, high and low pressure casting), additive layer manufacturing (ALM) processes (including blown powder and metal bed technologies), powder technologies (including hot isostatic pressing, Metal Injection Molding).

The following sections review contributions to the development of the research methodologies reported in Figure 2. For each category of contribution considered (i.e. Analytical, DFM Methodology etc) the process described in one, or more, of the papers belonging to that group is illustrate schematically to show the researcher's approach.

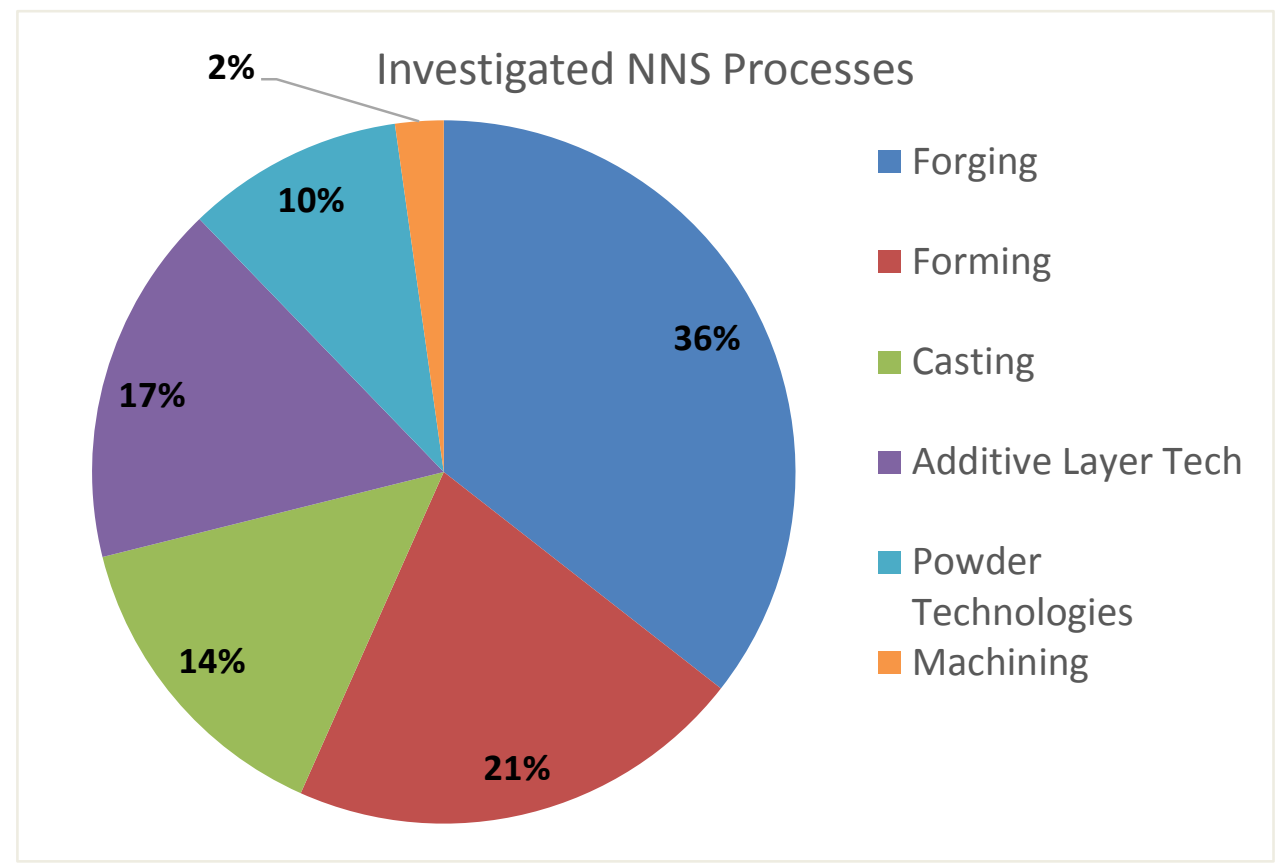

Figure 4: Percentage of NNS papers by Manufacturing Process. 


\section{Theoretical - Analytical}

The following papers report analytical models of NNS processes. Chitkara and Bhutta [8] develop an upperbound model for predicting forming loads in splined shaft forging (relative to their reduction ratio) and compares the results with experimental trials. Similarly, upper-bound models have been developed for forging of spur gears Chitkara and Bhutta [9] and crown gears Chitkara and Kim [10]. In a slightly different approach, Chitkara and Kim [11] use upper-bound and velocity field (i.e. various forging rate) for predicting loads in forging of gear coupling. Netto et al. [12] deploy a turbulent fluid flow, heat transfer and solidification model, investigating the strip casting dynamic and nozzle shape optimization. $\underline{\text { Kwak and }}$ Doumanidis [13] introduce a closed loop controller for optimizing material deposition in thermally scanned welding, extendable to other welding technologies. Jeon and Kim [14] compare two different analytic methods for simulating hot isostatic pressing and verifying them through a combination of FEM and previous experimental trials reported in the literature. Tomov and Gagov [15] (Figure 5) optimize the preform design of spur gears. The authors model, analytically, both the preliminary open die forgings operations and the final precision forging, correlating all manufacturing steps with preform dimensioning.

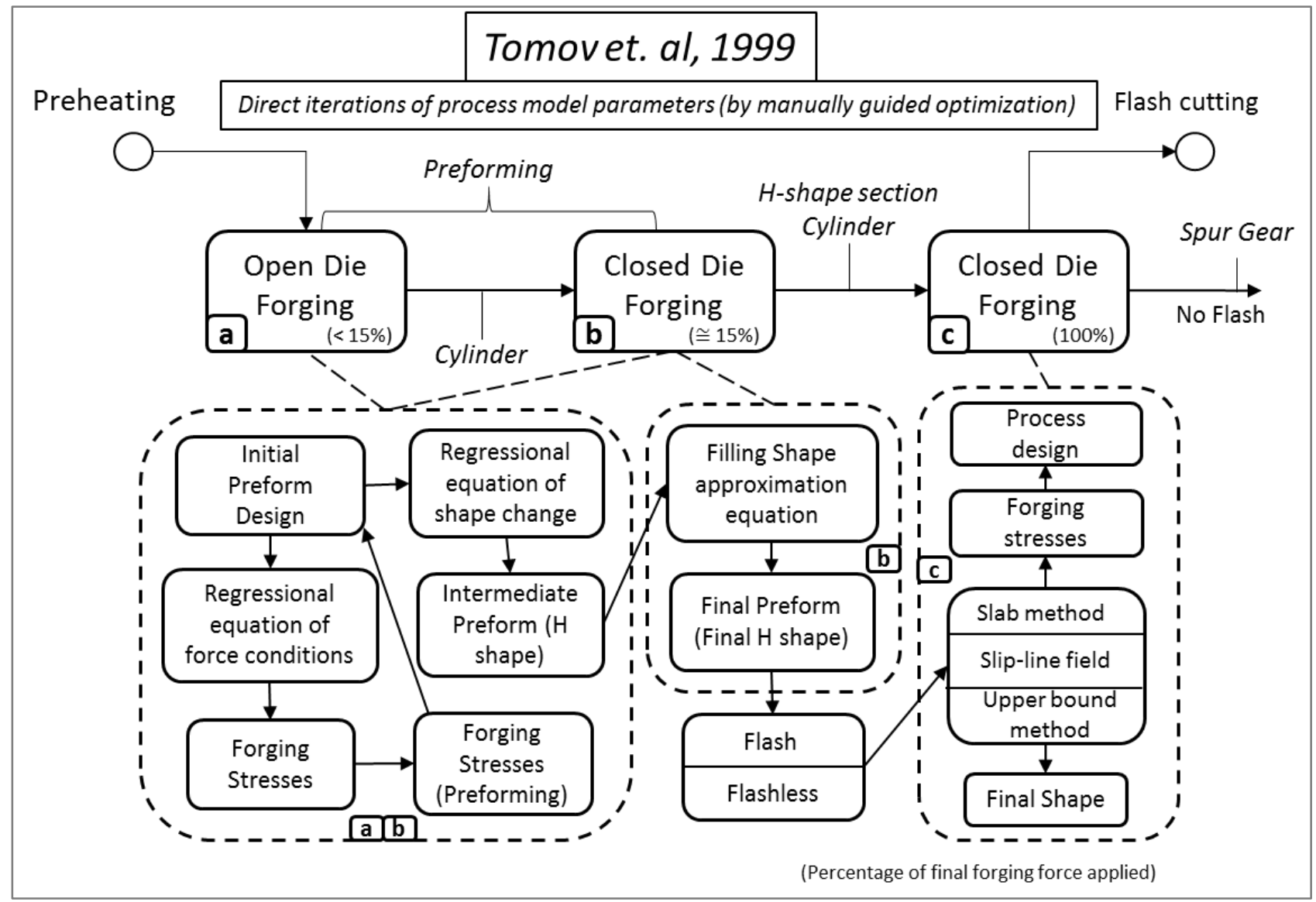

Figure 5: Schematization of Tomov and Gagov [15] procedure for analytical optimization of forging process. 


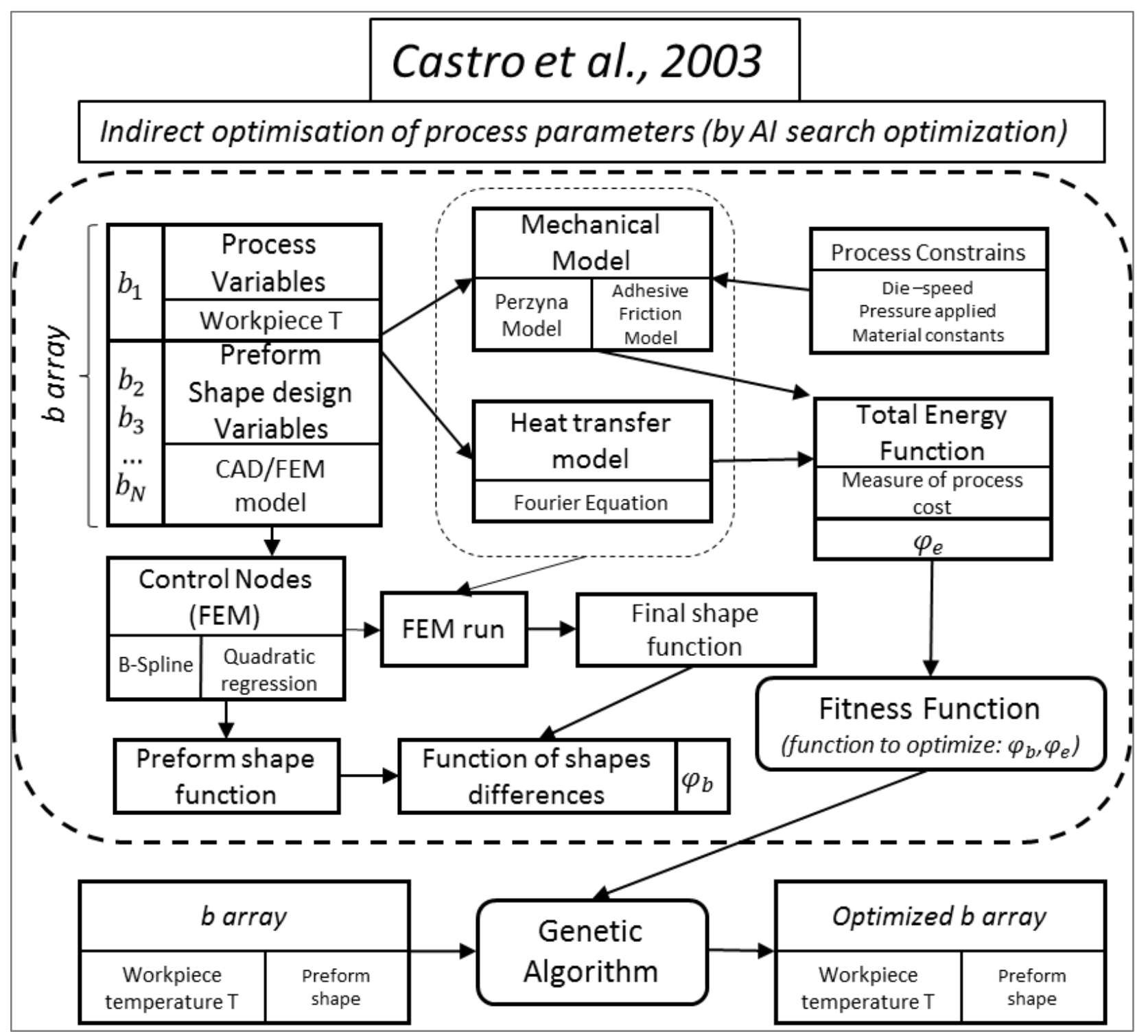

Figure 6: Schematization of the Castro et al. [16] Genetic Algorithm for optimizing closed hot die forging process in terms of preform shape and process temperature.

Castro et al. [16] (Figure 6) apply a genetic algorithm optimization to a numerical model, simulating a hot upset forging process. The evolutionary strategy provides process parameters and preform design optimization (described by a polynomial function). This approach is notable for its linking of process and resource optimization with process parameters and product design.

\section{Theoretical-Numerical}

The following papers report numerical models of NNS processes The maturing of this category of NNS investigation into a practical tools that could support Multiphysics models can be seen in the work of Hwang and Stoehr [4] who develop a solidification model for casting processes that included turbulent viscosity, surface tension and marker reduction scheme of molten metal, combining Lagrangian and Eulerian approach. 
Similar complexity of modeling is used in simulating isothermal forging process, Morita et al. [17] for optimize die design and preform positioning of turbine blade. Comparing to the classic forging process, the authors observe the superior properties of isothermal forged component (in terms of defects, mechanical and material properties and decreasing machining allowance). Li [18] uses finite elements for modeling the electromagnetic recirculation process during casting. Takemasu et al. [19] investigate precision forging process of connecting rod. Using material flow simulation, the authors optimized the preform design in this application (volumes definition and the effectiveness of die filling process are critical in precision forming). Initially they optimized the component by parts, dividing the rod in regions, before subsequently proposing a new preform design. Mamalis et al. [20] compare implicit and explicit approaches to modeling precision die forging. They concluded that implicit code results are more accurate, although that computational cost is higher. Okada et al. [21] deploy numerical models for forging of semisolid alloys and validates them with experimental results. The aim is to characterize the $\mathrm{Al}-\mathrm{Al}_{3} \mathrm{Ni}$ flow and deformation in semisolid state forging. Kim et al. [22] investigate numerically a centrifugal casting investment process (or centrifuging casting) of turbocharger rotors (TiAl alloy). Simulation provides information about mold filling, which, correlate well with experimental trials and can be used to resolve production problems such as the incomplete filling of dies. Park et al. [23] develop a bi-dimensional finite element model for characterize multistage forging of automotive parts (joint). The numerical model's aim is to develop a reliable forming process chain as well as to establish process parameters and stress analysis for a correct process design. Yuan et al. [24] (Figure 7) deploy a model for simulating hot isostatic pressing of axial-symmetric components. The tool design has been tested for obtaining dimensional proprieties of component and again experimental trials show good agreement between predicted and real geometries.

\section{DFM Methodologies}

The following papers report 'Design for X' methodologies relevant to NNS processes. Chu et al. [25] deploy a skeleton-based design analysis to extract topological information from a 3D model (Euler characteristics and connectivity). In this way, product features information are digitalized and computed through a dedicated algorithm. Using a heuristic knowledge base database, product design feasibility can be analyzed for different casting and forming technologies. De Sam Lazaro et al. [26] develop a feature recognition program for sheet metal parts. 


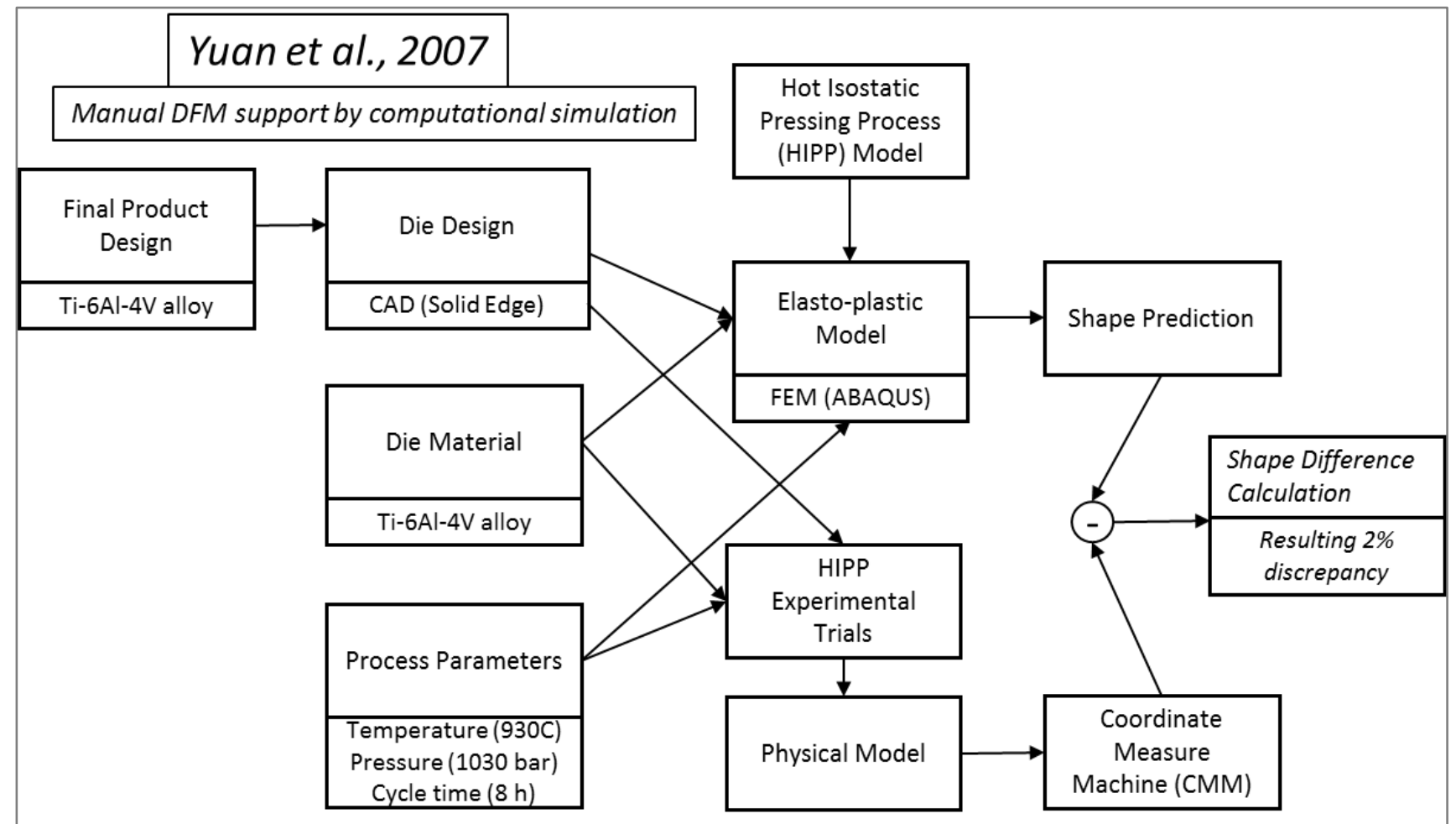

Figure 7: Yuan et al. [24] numerical investigation scheme for evaluating hot isostic pressing final shape prediction through FEM.

Program rules are able to represent sheet features and so represent a simple design as a digital object. This allows a knowledge base system to be configured, adapting DFM rules for this specific case. Using this program, multi stage forging of sheet component can be also evaluated and to provide feeback to the designer. Caporalli et al. [27] (Figure 8) report a CAD/FEM based Expert System that enables process design optimization for manufacturing by a precision hot forging process. Starting from a part design, the system applies dedicated NNS rules (e.g. minimizing machining allowances, selection of parting line, radii, drafts and fillets selection) and modifies the part design. After this forging sequence (to check the design's preforms) is created using either the job's similarity with previous routes or generated, according to selected criteria and matched to material, size and geometry of the part. Lastly, a die design is generated, considering preforms geometry, thermal expansion, and the use of standardized tools and inserts. Yin et al. [28] present a virtual prototyping approach for evaluating the feasibility of mold casting. Framework evaluates geometric mouldability of the component by recognizing and evaluating undercut features. The algorithm is capable of recognizing undercut features and giving multiple interpretations based on volume decomposition. The component volume is decomposed into cells in order to evaluate parting directions and feasibility. Konak et al. [29] estimate shrinkage in hot isostatic pressing using a neural net approach to create a predictive model 
based on industrial data (regression analysis). Medellin et al. [30] develop a decomposition and optimization procedure (Octotree) from a 3D model, which provides a subdivision of component into different sizes of cube. After stability analysis, an assembly sequence is generated and a robotic cell used to construct the component by collocating and binding the singular cubic volumes. Final component needs to be postmachined in order to obtain curve surfaces. Löwer et al. [31] review and deploy strategy for substituting conventional material (metal and plastic) and process. They identify and assess the technical, ecological and economic feasibility of this approach and use a systematic approach for matching technical requirements with biological characteristics.

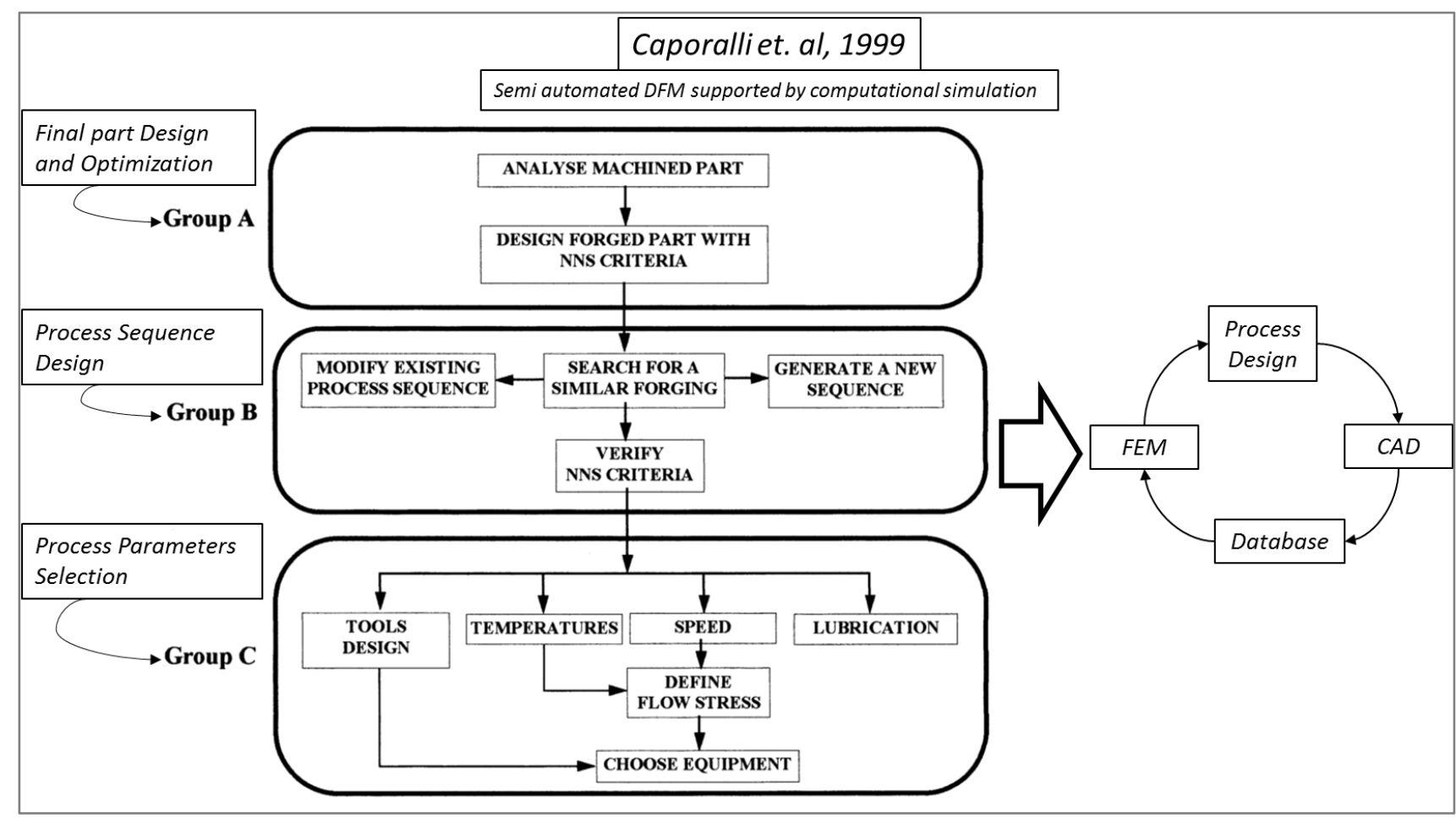

Figure 8: Caporalli et al. [27] Expert System flowchart with application to process design components.

\section{NNS Reviews}

The following papers review NNS processes methodologies and models: Doege and Thalemann [6] approach NNS by reviewing metal forming technologies for several applications (including squeeze casting and rolling). Existing technologies substitution (mainly machining) are explained and justified by the possibility of obtaining ready-to-install products. Kudo [32] surveys and summarizes previous industrial approaches and frameworks for quality control, comparing them with NNS approach. The author provides both general models and examples in forming and forging environments. Interaction between process controls (equipment and process parameters), workforce and the process chain workflow's design is detailed. Altan and Miller [7] 
review previous "design-for-forging" (hot, cold, warm and sheet forging) and "design-for-manufacturing" approaches. In the latter the author summarizes "design-for-net-shape-methodologies" and application, giving fundamental guidelines and definitions. Moriguchi [33] discusses the impact of cold forging (particularly injection forging) on production of gears and drive train components, including impact of CAE on process output. Similarly, Siegert et al. [34] summarize approaches for precision forming of aluminum and steel. The authors review die design and process parameter optimization (using FEM) for hot forging of connecting rods and helical gears. Similarly, Yoshimura and Tanaka [35] review precision forging methods for similar materials and details their possible applications. Kruth et al. [36] discuss possible future applications of additive layer manufacturing techniques in manufacturing production, presenting them as NNS processes. Doege and Bohnsack [37] evaluate the impact of innovative equipment and device optimization (particularly closing devices) on hot forging performances (e.g. reduction of forging loads). Dean [38] summarizes the benefit of several innovative forming technologies (i.e orbital, precision and closed die-forging) on spur and helical gears. The author reviews the impacts of these new technologies on final product properties and manufacturing chains. Mac Donald and Hashmi [39] review the impact of bulgeforming on tubes production, including process simulation and optimization. Mudge and Wald [40] synthesize possible application for freeform technology, including repairing, cladding and components manufacturing. Yamamoto et al. [41] investigate the potential of the Armstrong process, which provides titanium powders for sintering process. Mechanical properties and final densities obtained by the authors in previous experiments are compared as well as those reported for different powder forming technologies.

\section{Empirical - Experimental}

The following papers detail experimental investigations into NNS processes: a number of authors have reported investigations into the potential of semi-solid metal casting (SSMC) process for NNS applications: Witulski et al. [42] compare semi-solid metal casting and isothermal forging capabilities for aluminum alloys, mainly in terms of productivity and defects avoidance. Kang et al. [43] (Figure 9) examine different reheating methods for the semi-solid casting of aluminum components, comparing the resulting microstructure, mechanical and surface proprieties. Kapranos et al. [44] optimize a thixoforming die for minimizing defects in the production of end plates for electric motors. 


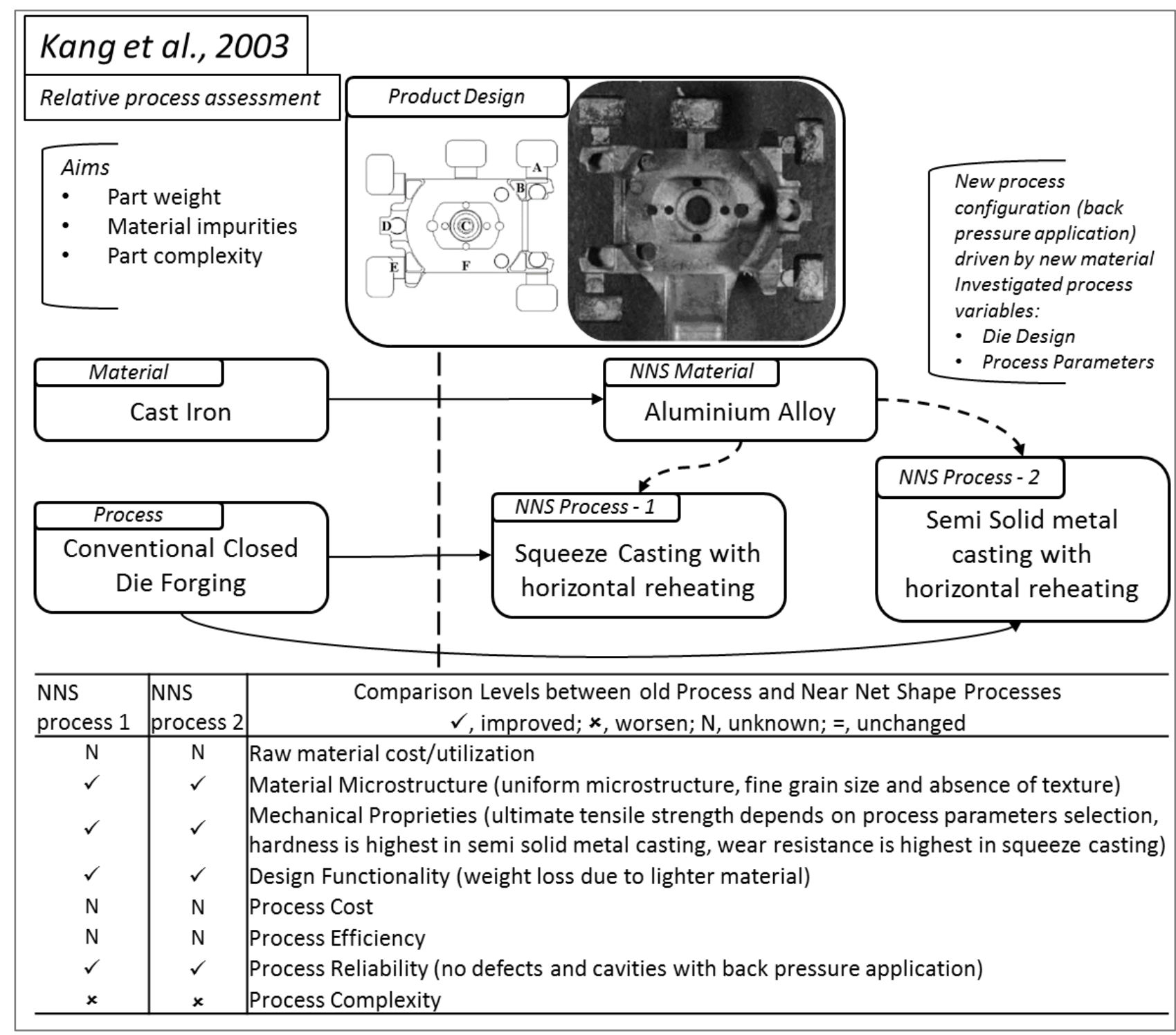

Figure 9: Schematic representation of Kang et al. [43] experimental paper on aluminum carter squeeze casting (old process, material, product design and new NNS tested process and material; investigation aims; NNS variables developments and comparison levels between new and old NNS process).

Yin et al. [45] develop and test horizontal-type induction heating for SSMC. Mechanical properties have been evaluated varying process parameters for a novel reheating method. Investigating rheocasting, Curle [46] report the results of microstructural analysis of Aluminum alloys produced by a number of different processes. Similarly other authors have reported material characteristics for several applications, characterizing materials behavior, or targeting material properties, through new or existent processes. Gupta and Ling [47] investigate Al-Si alloy properties (mechanical, thermal and fractural behavior) and microstructure arising from production of ingots using a disintegrated melt deposition technique. Material properties are also reported during the an investigation of the investment casting of automotive components 


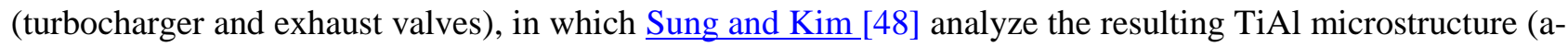
case formation) and fluidity.

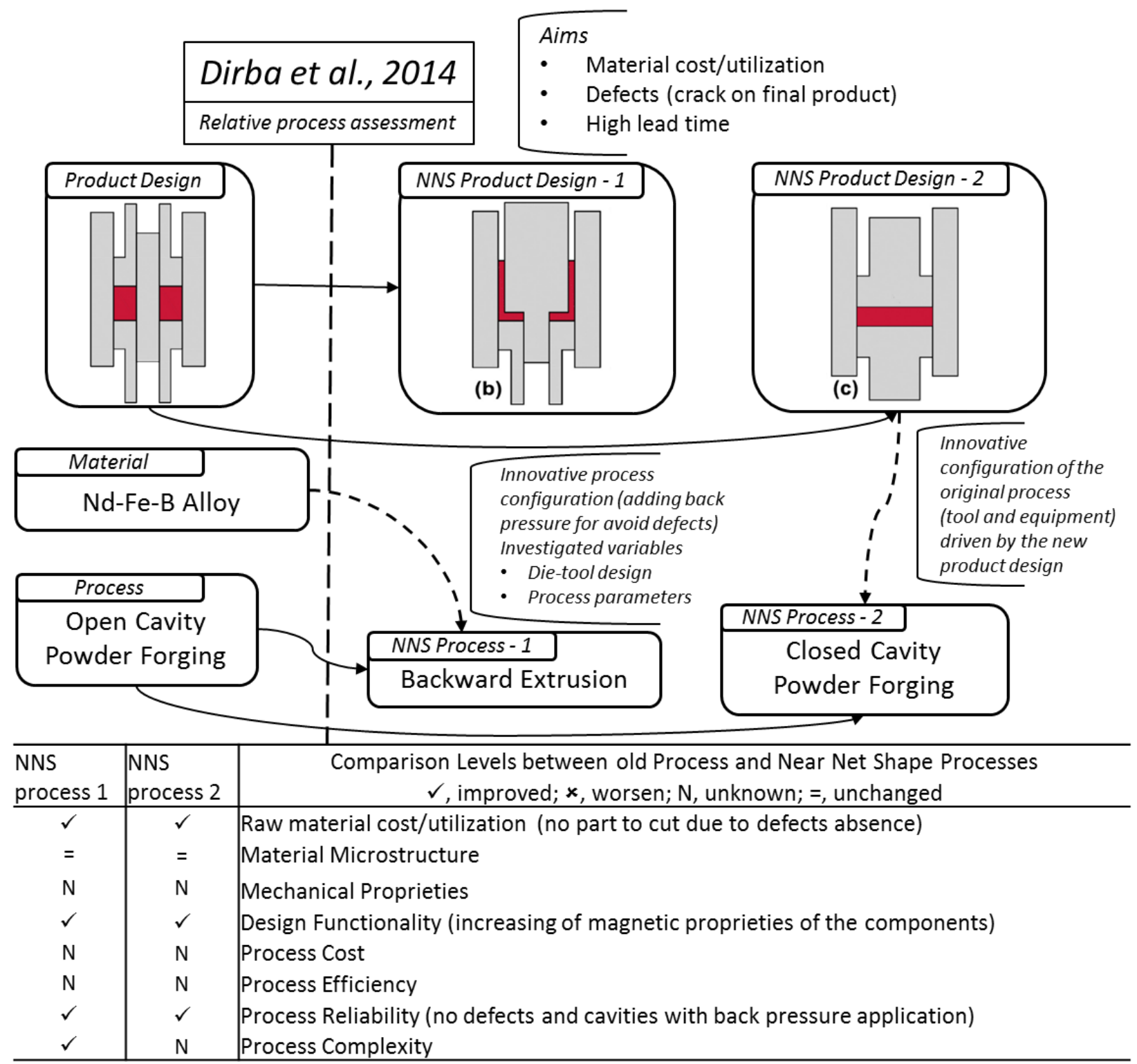

Figure 10: Schematic representation of Dirba et al. [49] experimental paper on magnet forging (old process, material, product design and new NNS tested processes and product designs; investigation motives and targets, NNS variables developments; comparison levels between old and NNS process).

For hot rolling, Arribas et al. [50] investigate dynamic and static recrystallization (dependent on grain size and deformation conditions during the process) as well as particles/precipitates inclusion of Ti alloys. Köhl et al. [51] develop a variant of MIM (Metal Injection Molding) for producing highly porous NiTi medical implants. Microstructure and mechanical properties control are performed using space-holders techniques (i.e. testing different material powders, injected with the metal and after chemically removed). Qi et al. [52] study heat treatment effects on microstructure and mechanical properties during a laser deposition process of 
Inconel alloys. Rapid manufacturing (a.k.a. additive layer manufacturing) has also been investigated by other authors, mainly treating them as NNS process for defined components geometries or materials. Lewis et al. [53] summarize the trials for direct light fabrication technology, including final components properties. Milewski et al. [54] use a 5-axis powder deposition to produce complex geometries from 316 stainless steel direct light fabrication (selective laser melting).

Investigating the production of NNS Inconel turbine components, Qi et al. [55] deploy a 'Design of Experiments' approach for systematically assessing the process parameters in laser net shape manufacturing (melting blown powder technology). Janney et al. [56] investigate a powder forging process (Gelcast) for producing tool steel and ceramic machinable green parts. Krishna et al. [57] experiment with LENS system (freeform fabrication) for NiTi alloys, displaying final mechanical and microstructural properties. Taminger and Hafley [58] investigate Electron Beam Forming process for aerospace components. Working with forming and forging processes, Hartley [59] investigates hot extrusion for lithium alloys, for aerospace application. The author tested different working condition and assessed the savings for the final machining step. Also Dirba et al. [49] (igure 10) use similar technology with low deformable alloys (Nd-Fe-B) for magnets production. Magnetic proprieties have been investigated as well as temperature stability and mechanical characteristics with the aim of enabling material waste reduction. Similar investigation has been conducted by Hinz et al. [60] for radially oriented magnets. Shi et al. [61] demonstrate the advantages of isothermal closed die forging for impeller production, using FEM analysis and experimental trials. Julien and Després [62] develop a novel low pressure metal injection molding (LMIM), process that is economic for low batch sizes. They report the application of the process to production of aerospace turbine blades and investigate the microstructure obtained. Working on strip casting, Liang et al. [63] investigate edge containment for Zn-10Al alloy. Bewlay et al. [64] develop roll forming for engine disk, comparing its microstructure, mechanical properties and material wastage with conventional hot forging process (Figure 11). Park et al. [65] investigate the machining of turbine blades and report the experimental optimization for tool positioning in the context of NNS production.

\section{Empirical - Case study}

The following papers report empirical results for NNS processes based on experimental investigations.

Onodera and Sawai [66] (igure 12) illustrate two example of NNS applications in automotive industry ( for 
spline shaft and joint productions), and introduce a general production scheme (inspired by Ishikawa tree's schematization) that supports quality control functions.

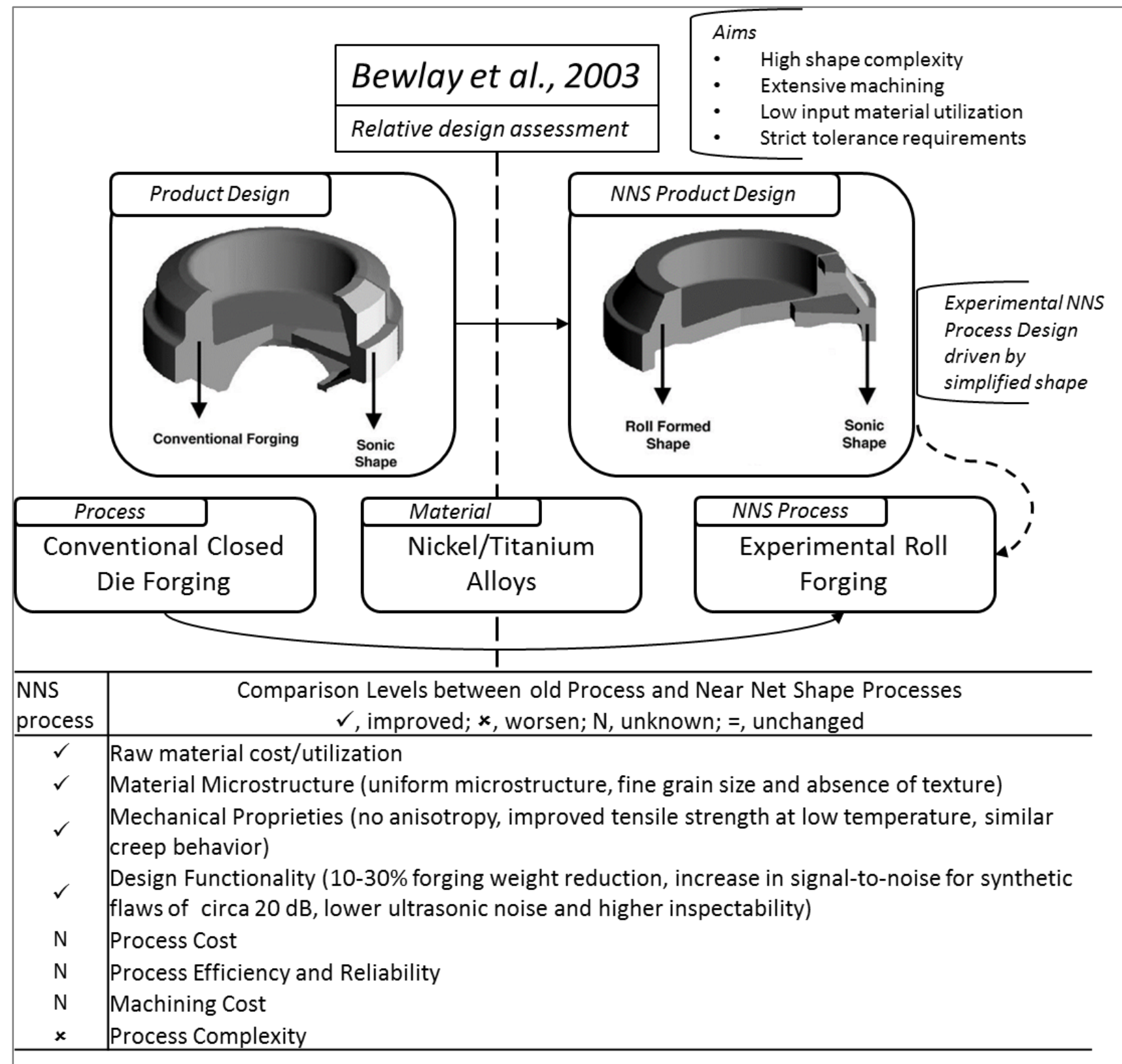

Figure 11: Schematic representation of Bewlay et al. [64] experimental paper on engine disk roll forging (old process, material, product design and new NNS tested process and product designs, investigation motives and Targets, NNS variables developments, comparison levels between old and NNS process).

Maegaard [67] illustrates the difference in process design (die and punch) and final quality for cold forging and backward extrusion, in the context of small batch production. Hirt et al [68] investigate potentiality of thixoforming for automotive components weight reduction, developing simulation and production optimization (process parameters). Quality, reliability and potential production volume of components are investigated in an industrial environment (where production is assisted by robotic device). Many authors

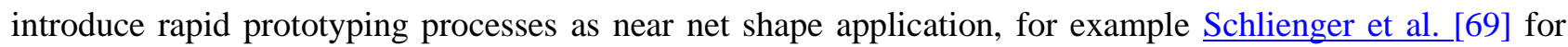




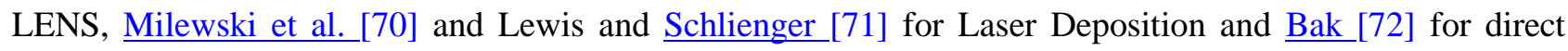
metal casting. Blackwell and Wisbey [73] compare final properties (mechanical properties and microstructure) using different LENS laser types and power compositions. Similarly, Kottman et al. [74] assess the feasibility of laser hot wire application for aerospace components (titanium). LaSalle and Zedalis [75] explain capabilities of Metal Injection Molding for high production volume and low weight component. Groenbaek and Birker [76] discuss the design about dies containers and the way in which die life-life increases impact on productivity. Dahlman and Escursell [77] introduce a tool cooling system for turning operation, which results in an increase in productivity. Douglas and Kuhlmann [78] illustrate some sensible improvement in material waste and quality, using precision forging processes. Cai et al. [79] test different die design and lubrication for the precision forging of gears. They examine the influences of different designs on metal flow and load requirements through experiments and finite element simulation. Friction factor has been evaluated experimentally and numerically during all stages of forging process. Friction distribution is shown to have a strong influence on the process of die filling. Klug et al. [80] synthetize different technologies (forging, forming and casting) for economic production titanium components and its impact on manufacturing of military equipment.

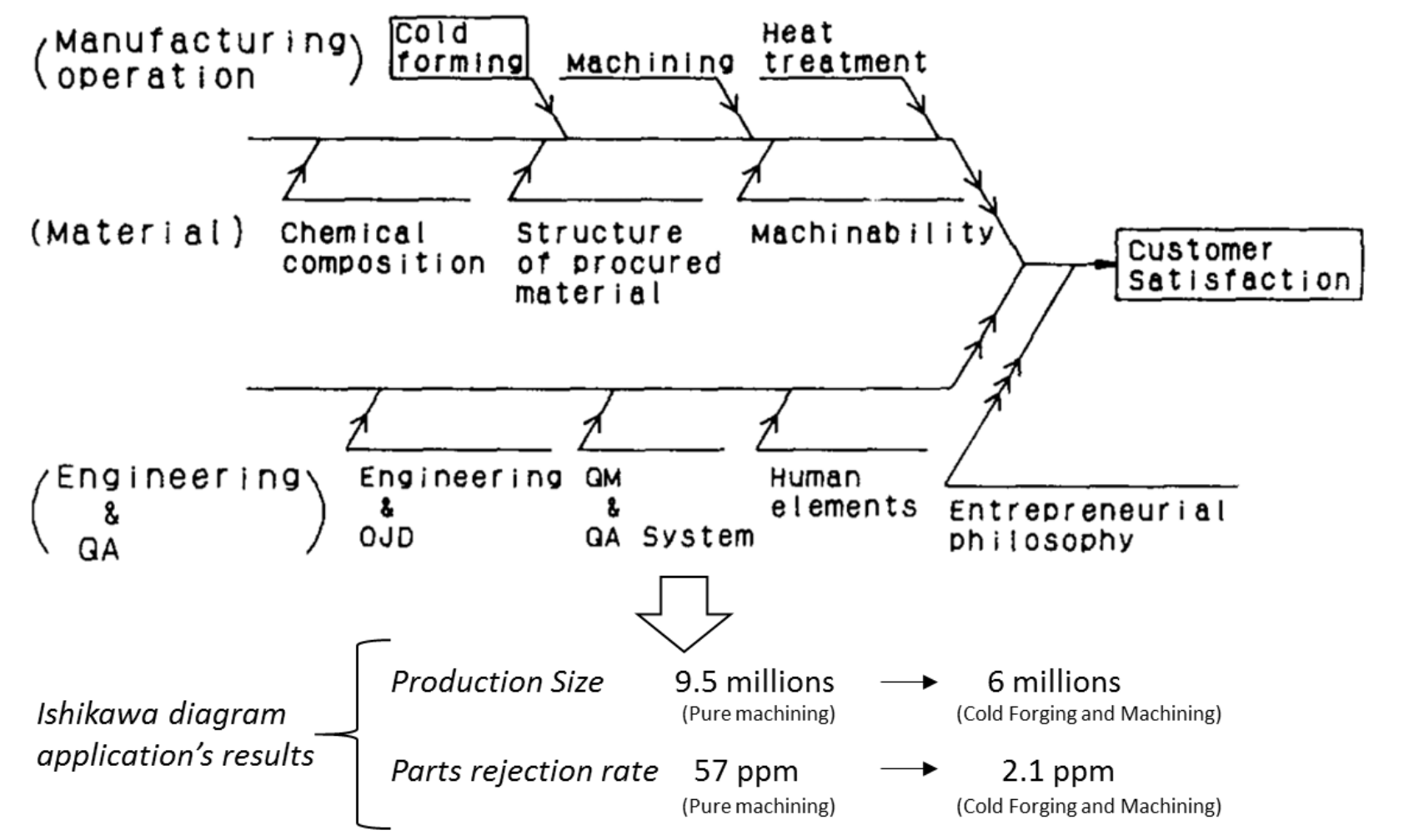

Figure 12: Onodera and Sawai [66] Ishikawa diagram for cold forging and results of its application 


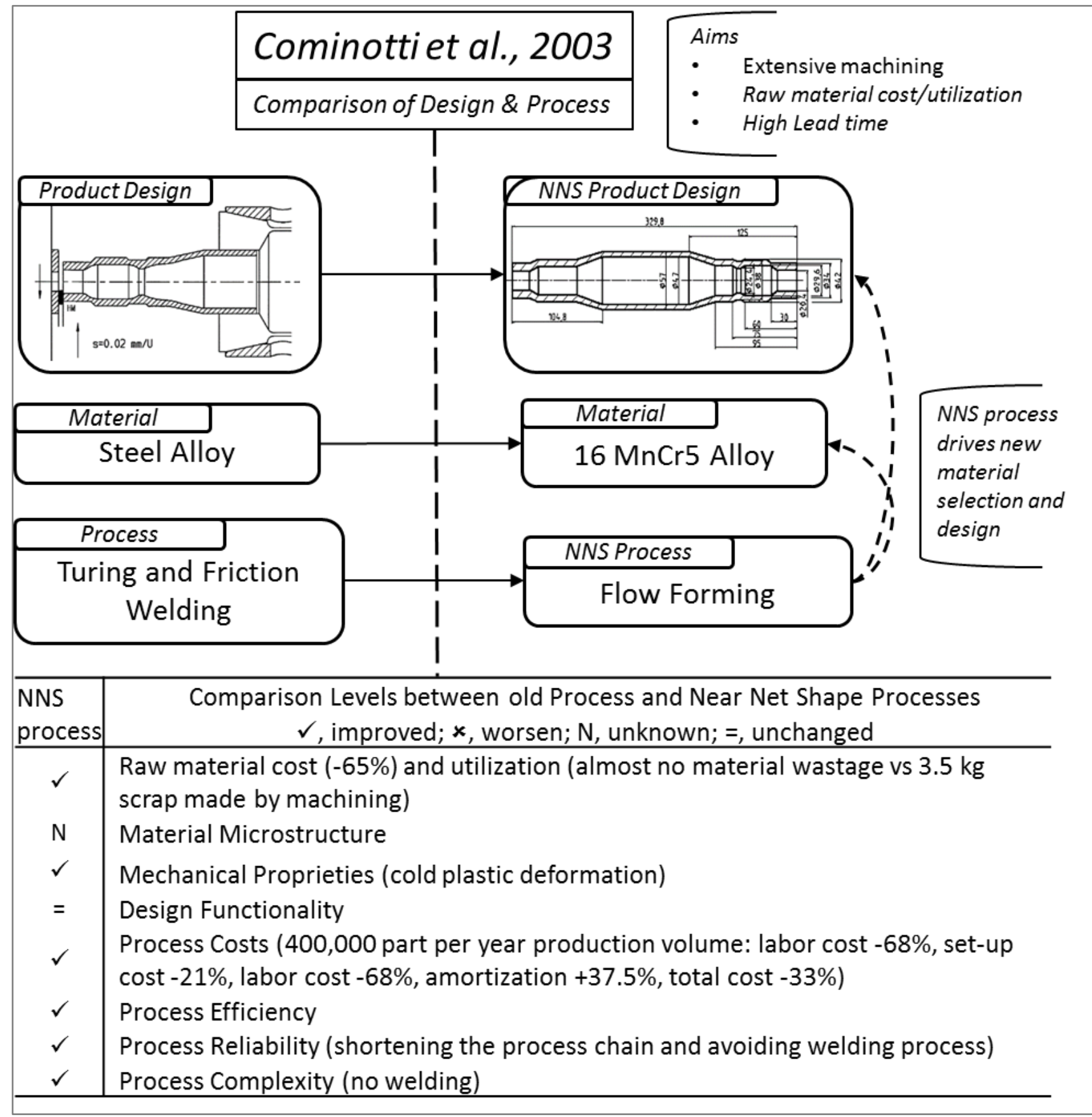

Figure 13: Schematic representation of Kang et al. [43] experimental paper (old process, material, product design and new NNS tested process, investigation motives and Targets, NNS variables developments and comparison levels).

Behrens et al. [81] and Vilotić et al. [82] both investigate the impact of precision (crankshafts, rods and gears) and cold forging (roller bearings and cardan joints), respectively for the production of automotive components. Cominotti and Gentili [83] (Figure 13) have compared flow forming and classical machining for a shaft production. The authors illustrate the different process chains (including technological advantages and disadvantages) and detail their impact on the different aspects of cost. A differential cost analysis is presented that considers flow forming as economic alternative to classic machining. 


\section{Empirical - Quantitative}

The following papers report quantitative relationships and data generated by NNS process case studies.

Tateno [84] investigate the differential processes capabilities for casting and forging process in the case of large size part production. Its investigation compares different materials and technological output, generated by different processes. Bhatkal and Hannibal [85] describes one of the few differential cost analysis and production capabilities mapping, for comparing MIM and Investment casting. Information about several components have been gathered using a technical cost modeling approach. A complete economic evaluation has been made in both cases and its sensitivity has been mapped by varying design and process parameters. Campbell [86] evaluate casting potentialities for several processes (sand casting, lost foam, lost wax, high pressure and low pressure/gravity casting). The dimensional variability of parts was investigated in relation to process variables, production dimensions and material. The author has been able to rank casting process regarding their potential dimensional accuracy (depending on casting dimensions). Table 2 summarizes the quantitative approaches methodologies and results.

Table 2: Quantitative approaches: investigated variables, tools, investigated effects, impact on NNS and conclusions.

\begin{tabular}{|c|c|c|c|c|}
\hline & & Campbell (2000) & Tateno et al. (1985) & Bhatkal et al. (1999) \\
\hline \multirow{3}{*}{ 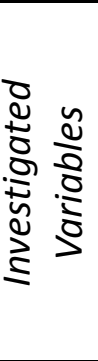 } & Materials & $\begin{array}{l}\text { Zinc, Magnesium, Aluminum alloy, Cast } \\
\text { Iron, Steel Alloy }\end{array}$ & Steel, Cast Iron & Pure Nickel \\
\hline & Processes & $\begin{array}{l}\text { Casting processes (pressure die, low } \\
\text { pressure/gravity die, high and low tech } \\
\text { sand casting, lost foam, lost wax) }\end{array}$ & $\begin{array}{l}\text { Open die Forging, Sand Casting, } \\
\text { Ingot manufacturing chain }\end{array}$ & $\begin{array}{l}\text { Metal Injection Molding (MIM), } \\
\text { Investment Casting }\end{array}$ \\
\hline & $\begin{array}{l}\text { Product } \\
\text { Designs }\end{array}$ & Nominal casting sizes $(10-1000 \mathrm{~mm})$ & $\begin{array}{l}\text { Large sizes component (nuclear } \\
\text { and chemical pressure vessels, } \\
\text { rotor shafts, water turbine } \\
\text { runners) }\end{array}$ & $\begin{array}{l}\text { Lightweight }(120 \mathrm{gr}) \text { and low } \\
\text { thickness }(3 \mathrm{~mm}) \text { components }\end{array}$ \\
\hline \multicolumn{2}{|c|}{ Tools } & $\begin{array}{l}\text { Cause- effect matrix, Statistical Survey } \\
\text { (variability dependency on casting } \\
\text { length }\end{array}$ & $\begin{array}{l}\text { Forging/casting processes } \\
\text { chains evolution, process } \\
\text { capability mapping, process } \\
\text { defects mapping }\end{array}$ & $\begin{array}{l}\text { TCM (Technical cost modelling), } \\
\text { Differential cost analysis, process } \\
\text { mapping }\end{array}$ \\
\hline \multicolumn{2}{|c|}{$\begin{array}{l}\text { Investigated } \\
\text { Effects }\end{array}$} & $\begin{array}{l}\text { Dimensional variability ( } \mathrm{mm}, \%) \text {, Casting } \\
\text { accuracy }(\mathrm{mm}, \%)\end{array}$ & $\begin{array}{l}\text { Quality improvements, Process } \\
\text { chains (casting and forging) } \\
\text { modification impact on } \\
\text { equipment, tools and process } \\
\text { parameters }\end{array}$ & $\begin{array}{l}\text { Process costs (Direct/Indirect) } \\
\text { modelling, Cost sensitivity to } \\
\text { production volume, process } \\
\text { variables and part weight, } \\
\text { Differential impact (\%) of voices of } \\
\text { cost }\end{array}$ \\
\hline \multicolumn{2}{|c|}{$\begin{array}{l}\text { Impact on NNS } \\
\text { technology }\end{array}$} & $\begin{array}{l}\text { Categorizing casting productions on } \\
\text { accuracy and dimensional variability } \\
\text { (evaluating and quantifying impact } \\
\text { factors) }\end{array}$ & $\begin{array}{l}\text { Identify best casting and forging } \\
\text { processes relating to big size } \\
\text { components production }\end{array}$ & $\begin{array}{l}\text { At equivalent (or satisfactory) } \\
\text { levels of processes' performances, } \\
\text { differential costa analysis need to } \\
\text { be structured for being a } \\
\text { comprehensive and adaptive } \\
\text { decision tool }\end{array}$ \\
\hline \multicolumn{2}{|c|}{$\begin{array}{l}\text { Main } \\
\text { Conclusions }\end{array}$} & $\begin{array}{l}\text { Lost wax is the most accurate only for } \\
\text { small sizes castings. Pressure die and } \\
\text { high quality sand have greatest } \\
\text { reproducibility for all dimensions and } \\
\text { materials) }\end{array}$ & $\begin{array}{l}\text { Pointing out progress made in } \\
\text { mega parts production, } \\
\text { including technical details for } \\
\text { casting and forging (process } \\
\text { chains and parameters) and } \\
\text { managerial aspects (R\&D) }\end{array}$ & $\begin{array}{l}\text { MIM in convenient over } \\
\text { investment casting only for a very } \\
\text { high production volume (million } \\
\text { pieces magnitude) for the specific } \\
\text { product requirements }\end{array}$ \\
\hline
\end{tabular}




\section{Discussion}

Although they deal with many different NNS technologies, the discussed papers can be classified into five distinct classes (Table 3). Altan and Miller [7] observed that part design, material and process play fundamental roles in NNS technology, taxonomy in the tables has been defined as process innovation, process design, product design, material characterization, differential.

\section{Process Innovation}

The "Process Innovation" papers introduce a new process $[\underline{36}, \underline{39}, \underline{56}, \underline{69}]$ or illustrate its capabilities and main variables for a defined range of products $[\underline{33}, \underline{35}, \underline{38}, \underline{61}, \underline{75}, \underline{76}, \underline{80-82]}$ and materials $[\underline{36}, \underline{53}, \underline{54}, \underline{56}$, $\underline{80]}$. The process innovation's classification is dominated by work on forging/forming $[\underline{33}, \underline{35}, \underline{38}, \underline{39}, \underline{61}, \underline{76}$, $\underline{81}, \underline{82}]$ and additive layer manufacturing $[\underline{36}, \underline{40}, \underline{53}, \underline{54}, \underline{69]}$ processes, although a few articles investigate novel powder technologies [56, 75] and casting [80] processes. The majority of the papers in this category present case studies $[35, \underline{38}, \underline{54}, \underline{76}, \underline{80-82]}$ and reviews [33, $\underline{36}, \underline{39}, \underline{40]}$, although some experimental investigation are reported for powder technologies [56, 75] and additive layer manufacturing [53, 69]. The applications motivating work in this area are the forging of gears $[\underline{33}, \underline{38}, \underline{76}]$, similar high performance automotive components $[\underline{35}, \underline{81}, \underline{82}]$ (i.e. bearings, cardan shafts, rods) and impellers $[\underline{61}, \underline{75}]$. Tool design [35], particularly die-design for forging [ $\underline{33}, \underline{38}, \underline{76}$, and new process configuration [39] is also frequently investigated by authors. Process parameters and variables for new processes are determined by several authors $[\underline{36}, \underline{38}, \underline{39}, \underline{56}, \underline{82}]$, again mainly for forging processes and powder technologies.

\section{Process Design}

"Process design" papers aim to into establish $[\underline{8-11}, \underline{14}, \underline{20}, \underline{55}, \underline{58}, \underline{68]}$, optimize $[12, \underline{22}, \underline{34}, \underline{44]}$ or enhance $[\underline{18}, \underline{43}, \underline{49}$ process capabilities in terms of technological quality $[\underline{8}, \underline{11}, \underline{18}, \underline{43}, \underline{44}, \underline{49}, \underline{68}]$, geometric capabilities $[\underline{9}, \underline{10}, \underline{14}, \underline{20}, \underline{55}]$, workable material $[\underline{12}, \underline{34}, \underline{58}]$ or waste reduction. Investigations are mainly empirical (experimental and case studies) and analytical $[\underline{8-12,} \underline{14}]$. The empirical ones focus on forming, particularly on enhancing and optimizing Semi Solid Metal Casting (SSMC) processes in term of the technological quality $[\underline{43}, \underline{44}, \underline{68}]$ or for additive layer manufacturing processes establish workable materials [됴] or geometric capabilities [5] . Analytical papers are focused on determining achievable geometries [9, $\underline{10}, \underline{141}$ and technological quality $[\underline{8}, \underline{11}]$ as well as optimizing workable materials $[\underline{12}]$ in forging process applications. Analytical analysis on material optimization have also been conducted for powder technologies 
$[\underline{8-12}, \underline{14}]$. Much of the work on numerical analysis enhance and optimize the quality of casting, particularly investment casting $[\underline{18}, \underline{22}]$, and also defining the component shapes achievable by forging [20].

\section{Product Design}

"Product design" papers aim to evaluate, modify and establish the influence of product design on process performances $[\underline{19}, \underline{29}$, feasibility $[\underline{25}, \underline{26}, \underline{28}]$, design $[\underline{15}, \underline{28}, \underline{30}]$ and final product quality [어]. DFM methodologies are mainly used in this category $[\underline{15}, \underline{19}, \underline{25}, \underline{26}, \underline{28-30]}$, it is interesting to notice that only two papers have investigated forging with different methodologies, one numerically (i.e. regarding cost performances improvement [19]) and the other analytically (i.e. regarding process design [15]). DFM methodologies have also been applied for determining the feasibility of forming [25, 26] and casting processes [28]. The approach is a powerful one and processes chains and process parameters have been designed using DFM methodologies for casting [28], forming and additive layer manufacturing [30]. DFM methodologies have been used for predicting the final product quality (i.e. shrinkage) and performances (i.e. quantify ideal shape modifications) in powder technologies (HIP) [29].

\section{Material Characterization}

"Material characterization" papers define metal properties in connection with a new process $[\underline{62}, \underline{74}]$ (e.g. Low pressure Metal Injection Molding, LMIM, and laser hot wire process, ALM process) or existing process

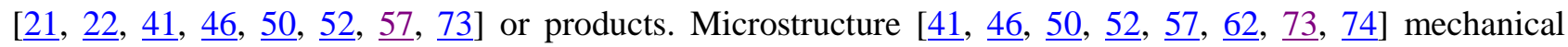
properties $[52,57, \underline{62}, \underline{73]}$, plastic flow/behavior [21] and other material processing parameters (e.g. fluidity, strain curve) $[\underline{22}, \underline{41}, \underline{50}]$ are commonly investigated material properties. Titanium $[\underline{22}, \underline{41}, \underline{46}, \underline{50}, \underline{73}, \underline{74}]$ is the most investigates material, because of its excellent mechanical proprieties, versatility and high cost but it is not the only focus and other papers investigate specific alloys such as: Aluminum-Titanium [21], NickelTitanium [57] and Inconel alloys $[\underline{52}, \underline{57}$. The majority of the articles is experimental $[\underline{46}, \underline{50}, \underline{52}, \underline{57}, \underline{62}, \underline{74}]$ or case study [73, 74], although it is surprising to note that only one use a Design of Experiments approach [52]. Two papers investigate titanium behavior for centrifugal casting [22] and semi-solid metal casting [21] with numerical models. Forming [50], particularly SSMC [21, 46], additive layer manufacturing and powder technologies processes are the most investigated for material characterization. 
Table 3: Overview of the NNS research: Process innovation, Process Design, Product Design, Material Characterization, Differential Analysis, Applied framework

\begin{tabular}{|c|c|c|c|c|c|c|}
\hline Stream & Process Innovation & Process Design & Product Design & $\begin{array}{l}\text { Material } \\
\text { Characterization }\end{array}$ & Differential analysis & Applied Framework \\
\hline $\begin{array}{l}\text { Construct } \\
\text { variants }\end{array}$ & $\begin{array}{l}\text { Process analysis, Process } \\
\text { definition }\end{array}$ & $\begin{array}{l}\text { Process Characterization, } \\
\text { Process Modeling, } \\
\text { Process Optimization }\end{array}$ & $\begin{array}{l}\text { Adaptive design, } \\
\text { Design For X, } \\
\text { Parametric Design, } \\
\text { Design Analysis, } \\
\text { Virtual Prototyping }\end{array}$ & $\begin{array}{l}\text { Microstructure analysis, } \\
\text { Microstructure } \\
\text { development }\end{array}$ & $\begin{array}{l}\text { Experimental analysis, } \\
\text { Differential cost analysis }\end{array}$ & $\begin{array}{l}\text { Expert System, } \\
\text { Framework, Flowchart, } \\
\text { Algorithm }\end{array}$ \\
\hline Description & $\begin{array}{l}\text { Introducing a new process } \\
\text { or describing its } \\
\text { capabilities and main } \\
\text { variables for a defined } \\
\text { range of product and } \\
\text { materials }\end{array}$ & $\begin{array}{l}\text { Establish, optimize or } \\
\text { enhance process } \\
\text { capabilities in terms of } \\
\text { technological quality, } \\
\text { geometric capability, } \\
\text { workable material and } \\
\text { waste reduction }\end{array}$ & $\begin{array}{l}\text { Evaluate/modify/establ } \\
\text { ish influence of product } \\
\text { design on process } \\
\text { performances/feasibilit } \\
\text { y/ design and final } \\
\text { product quality }\end{array}$ & $\begin{array}{l}\text { Material properties } \\
\text { (microstructure, } \\
\text { mechanical, plastic } \\
\text { behavior ...) definition in } \\
\text { connection with a } \\
\text { developed or existent } \\
\text { process/product. }\end{array}$ & $\begin{array}{l}\text { Compare different } \\
\text { processes and/or product } \\
\text { designs and/or materials } \\
\text { by considering economic } \\
\text { and/ or technological } \\
\text { output } \\
\text { (product quality/ } \\
\text { conformity/ proprieties) }\end{array}$ & $\begin{array}{l}\text { Introducing general } \\
\text { models or dedicated } \\
\text { procedures in order to } \\
\text { act on manufacturing } \\
\text { variables (process, } \\
\text { product design, material) } \\
\text { and obtaining resources } \\
\text { saving }\end{array}$ \\
\hline $\begin{array}{l}\text { Key } \\
\text { Concepts }\end{array}$ & $\begin{array}{l}\text { Process capabilities } \\
\text { mapping, Process } \\
\text { variables, Innovative } \\
\text { process configuration and } \\
\text { equipment (e.g. new die } \\
\text { design) }\end{array}$ & $\begin{array}{l}\text { Experimental } \\
\text { characterization, Design } \\
\text { of Experiments, Process } \\
\text { Modeling (FEM, } \\
\text { Analytic), }\end{array}$ & $\begin{array}{l}\text { Geometric modeling, } \\
\text { Geometric feasibility, } \\
\text { Process feasibility, } \\
\text { Preform design }\end{array}$ & $\begin{array}{l}\text { Formability, Mechanical } \\
\text { properties, Fluidity, } \\
\text { Recrystallization, } \\
\text { Product quality }\end{array}$ & $\begin{array}{l}\text { Process comparison, } \\
\text { Economic evaluation, } \\
\text { Economic model, }\end{array}$ & $\begin{array}{l}\text { General Model, } \\
\text { Systematic Approach, } \\
\text { Multi-subject approach, } \\
\text { Adaptive frame }\end{array}$ \\
\hline $\begin{array}{l}\text { Papers } \\
\text { number }\end{array}$ & $\begin{array}{c}24 \\
(29 \% \text { of the total) }\end{array}$ & $\begin{array}{c}29 \\
(35 \% \text { of the total) }\end{array}$ & $\begin{array}{c}7 \\
\text { (9\% of the total) }\end{array}$ & $\begin{array}{c}11 \\
(13 \% \text { of the total })\end{array}$ & $\begin{array}{c}7 \\
\text { (9\% of the total) }\end{array}$ & $\begin{array}{c}6 \\
\text { (7\% of the total) }\end{array}$ \\
\hline Main Works & $\begin{array}{l}\underline{\text { Schlienger et al.[69]; LaSalle }} \\
\text { \& Zedalis [75]; Groenbaek \& } \\
\text { Birker [76]; Lewis et al. [53]; } \\
\text { Milewski et al. [54]; Klug et } \\
\text { al. [80]; Behrens et al. [81]; } \\
\text { Vilotić et al. [82]; Dean [38]; } \\
\text { Moriguchi [33]; Kruth et al. } \\
\text { [36]; Yoshimura \& Tanaka } \\
\text { [35]; Mac Donald \& Hashmi } \\
\text { [39]; Mudge \& Wald [40]; } \\
\text { Janney et al.[56]; } \text { Shi et al. } \\
\text { [61] }\end{array}$ & $\begin{array}{l}\text { Li [18]; Hirt et al. [68]; Kim } \\
\text { et al. [22]; Chitkara \& } \\
\text { Bhutta [8]; Chitkara \& Kim } \\
\text { [10]; Chitkara and Bhutta } \\
\text { [9]; Chitkara \& Kim [11]; } \\
\text { Netto et al. [12]; Jeon \& } \\
\underline{\text { Kim [14]; Siegert et al. }} \\
\text { [34]; Kapranos et al. [44]; } \\
\underline{\text { Kang et al. [43]; Qi et }} \\
\text { al.[55]; Taminger \& Hafley } \\
\text { [58]; Dirba et al.[49]; } \\
\text { Mamalis et al. [20] }\end{array}$ & $\begin{array}{l}\text { Takemasu et al. [19]; } \\
\text { Tomov \& Gagov [15]; } \\
\text { Chu et al..[25]; De Sam } \\
\text { Lazaro et al. [26]; Yin et } \\
\text { al. [28]; Konak et al. [29]; } \\
\text { Medellin et al. [30] }\end{array}$ & $\begin{array}{l}\text { Blackwell \& Wisbey [73]; } \\
\text { Kottman et al. [74]; Okada } \\
\text { et al. [21]; Yamamoto et al. } \\
\text { [41]; Curle [46]; Kim et al. } \\
\text { [22]; } \underline{\text { Arribas et al.[50]; Qi }} \\
\text { et al. [52]; Krishna et al. } \\
\text { [57]; Julien \& Després [62] }\end{array}$ & $\begin{array}{l}\underline{\text { Tateno [3]; Bhatkal \& }} \\
\text { Hannibal [85]; Cominotti \& } \\
\underline{\text { Gentili [83]; Witulski et al. }} \\
\text { [42]; Morita et al.[17]; } \\
\underline{\text { Campbell [86]; Bewlay et }} \\
\underline{\text { al. [64] }}\end{array}$ & $\begin{array}{l}\text { Onodera \& Sawai [66]; } \\
\text { Castro et al.[16]; Altan \& } \\
\text { Miller [7]; Caporalli et al. } \\
\text { [27]; Löwer et al. [31]; } \\
\text { Kudo [32] }\end{array}$ \\
\hline
\end{tabular}




\section{Differential Analysis}

In the category "Differential analysis", papers compare different processes $[\underline{17}, \underline{42}, \underline{85}]$ or different processes with different product designs $[\underline{64}, \underline{86}]$ or even different combinations of processes, product designs and materials $[\underline{83}, \underline{84]}$. Authors use comparison criteria which include process economics [83, 84] and technological output evaluations $[\underline{17}, \underline{42}, \underline{64}, \underline{85}, \underline{86}]$. The technological output evaluation considers product quality, product conformity and the generic proprieties (e.g. part weight, vibrational characteristics). The latter are final product characteristics which are not described as quality or conformity requirements (i.e. depending on the specific product application). Three paper use quantitative approach [84-86], comparing different casting processes [86], casting and powder technologies (MIM) [85] as well as casting and forging [84]. Isothermal forging has been used as benchmark for comparison of several processes: experimentally for roll forging [64] and semi-solid metal casting (SSMC) [42] and numerically for closed die forging [17]. The only case study reports an economic comparison between flow forming and friction welding/machining [83].

\section{Applied framework}

"Applied framework" papers introduce general models $[\underline{7}, \underline{31}, \underline{32]}$ or adaptive procedures $[\underline{16}, \underline{27}, \underline{66}]$ for determining manufacturing variables (process, product design, material) in order to obtain resources saving $[\underline{7}, \underline{16}, \underline{31}, \underline{32}]$, quality enhancing [6ㅜ] or process design optimization (i.e. process parameters selection) [ㄱ, $\underline{16}, \underline{27}]$. The majority of the papers analyze process and product variable combinations $[\underline{16}, \underline{32}, \underline{66}$, but only one consider the combination of process, product and material [31]. Two of them are taking in consideration only process variation $[\underline{7}, \underline{27}]$. Main application of work in the class is the forging process $[\underline{7}, \underline{16}, \underline{27}, \underline{66}]$, although two articles include casting [31] and forming [32] in their frameworks. Resource saving is the main motivation (i.e. raw material usage reduction $[\underline{7}, \underline{16}, \underline{31]}$ ), because of its high impact on forging cost. DFM methodologies $[\underline{27}, \underline{31}]$ and reviews $[\underline{7}, \underline{32}]$ have been used for constructing the frameworks, although the following report different approaches: an Ishikawa diagram for cold forging [66] is constructed through a case study and one analytical approach use a Genetic Algorithms [16] for developing a preform design methodology. 


\section{Closing Remarks}

Near net shape manufacturing is a multi-disciplinary task and consequently approaches are varied and often driven by the nature of the specific application. The literature reflects how NNS philosophies have evolved over the years to include almost all the main manufacturing techniques. So although initially the phrase was only used in reference to plastic deformation processes, NNS concepts have now been extended to casting and powder technologies and are implicit in the justification of many specialist forming processes (e.g. flow forming, hydroforming, SSMC) [리 $\underline{39}, \underline{42-44}, \underline{46}, \underline{68}, \underline{83}]$, powder technologies (HIP, MIM) $[\underline{62}, \underline{85}]$ and additive layer manufacturing systems $[\underline{36}, \underline{40}, \underline{52-55}, \underline{57}, \underline{58}, \underline{69}, \underline{73}, \underline{74}]$. Indeed today the term NNS is frequently used to convey the generic capabilities of manufacturing technologies and distinguish them from systems that aim to deliver finished components. The literature also highlights that NNS has been associated with the creation of advantageous process and material combination for particular designs whose form has been manually tailored for that purpose. Interestingly there appears to be a lack of general frameworks or $\mathrm{CAM} / \mathrm{CAD}$ tools to support the general process of 'Design for NNS' (i.e the reported tools $[2, \underline{25-27]}$ are largely focused on support of specific processes such as casting, closed die forging and injection molding). Similarly the general interactions between material, design and process are only rarely, formally investigated (even although this is an area of work suggested by many authors) $[\underline{7}, \underline{32}]$.

The literature demonstrates that innovative NNS systems are still emerging but although researchers frequently report new technologies the impact of these contributions on cost and the overall workflow in a

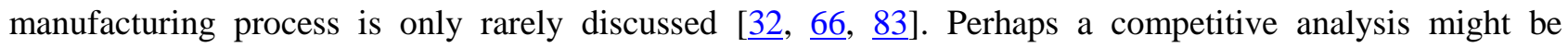
undertaken for a number of candidate processes (usually no more than two) but the scope of such analysis is often limited by the lack of flexibility in a component's material and design. A comparative cost analysis is a fundamental instrument for justifying every investigation into the desirability of NNS technologies. The few differential cost analysis reported in the literature are mainly case study [푸, $\underline{85}]$, where only different process alternatives have been evaluated (i.e. without considering alternate materials or designs). There appear to be no reports of work connecting systematic methodologies for process (e.g. Swift) and material (e.g. Ashby) selection. 


\section{Conclusion}

This review has identified and categorized the reported work on Near Net Shape manufacturing over the last thirty years. The process of creating a structured summary of the field has resulting in the identification of several knowledge gaps and trends in the academic literature. It is clear that the NNS approach has evolved from being a generic term to a specific family of processes and technologies. The early sections showed that the total literature (relating to all various aspects of NNS manufacturing) is now extensive and consequently the scope of this paper has been restricted to metals. So further work is needed apply to a systematic literature review methodology to the processes for materials which fell outside the scope of this paper (e.g. ceramic and composites) This additional breadth would help to better define the common approaches and, perhaps, more clearly identify the generic NNS research opportunities and limitations. However the authors believe that, even given the necessary limitations of this paper, the attempt to completely summarize the NNS manufacturing approach for the first time is a useful contribution that will focus and stimulate further work in this important area.

\section{Acknowledgements}

The authors want to thank WARC (Weir Advanced Research Centre), DMEM (Department of Design, Manufacturing and Engineering management) of the University of Strathclyde and Weir Group PLC for the fundamental and continuous support in this research.

\section{References}

[1] Boothroyd J, Dewhurst P. Design for Assembly: a designers handbook. University of Massachusetts, Dept. of Mechanical Engineering, 1983.

[2] Ishii K, Hornberg L, Liou M. Compatibility-based Design for Injection Molding. In: Proceedings of the Concurrent Product and Process Design Simposium, ASME Winter Annual Meeting. 1989, p. 153.

[3] Tateno M. Size High Quality Steels and Their Material as 'Near Net Shape'. Trans Iron Steel Inst Japan 1985; 25.

[4] Hwang W, Stoehr RA. Molten metal flow pattern prediction for complete solidification analysis of near net shape castings. Mater Sci Technol; 4: 240-250.

[5] Mathur P, Apelian D, Lawley A. Analysis of the spray deposition process. Acta Metall; 37: 429-443.

[6] Doege E, Thalemann J. Near Net-Shape Forming in Sheet-Metal Forming and Forging. Ann CIRP; 38: 609-616.

[7] Altan T, Miller RA. Design for Forming and other Near Net Shape Manufacturing Processes. CIRP Ann - Manuf Technol; 39: 609-620. 
[8] Chitkara N., Bhutta M. Near net shape spline forging: An experimental investigation and a simple upper bound analysis. Int J Mech Sci; 37: 1247-1268.

[9] Chitkara NR, Bhutta M a. Near-net shape forging of spur gear forms: An analysis and some experiments. Int J Mech Sci; 38: 891-916.

[10] Chitkara NR, Kim YJ. Near-net shape forging of a crown gear: Some experimental results and an analysis. Int J Mach Tools Manuf; 41: 325-346.

[11] Chitkara NR, Kim Y. Upper bound analysis of near-net shaped forging of gear coupling form. Int J Mech Sci; 38: 791-803.

[12] Netto PQ, Tavares RP, Guthrie RIL. Mathematical models for near net shape casting process. ISIJ Int; 36: S175-S178.

[13] Kwak YM, Doumanidis CC. Geometry regulation of material deposition in near-net shape manufacturing by thermally scanned welding. J Manuf Process; 4: 28-41.

[14] Jeon YC, Kim KT. Near-net-shape forming of 316L stainless steel powder under hot isostatic pressing. International Journal of Mechanical Sciences; 41: 815-830.

[15] Tomov BI, Gagov VI. Modelling and description of the near-net-shape forging of cylindrical spur gears. J Mater Process Technol; 92-93: 444-449.

[16] Castro CF, António C a C, Sousa LC. Optimisation of shape and process parameters in metal forging using genetic algorithms. J Mater Process Technol; 146: 356-364.

[17] Morita A, Hattori S, Tani K, et al. Near Net Shape Forging of Titanium Alloy Turbine Blade. ISIJ Int; 31: 827-833.

[18] Li BQ. A finite-element analysis of magnetically driven recirculating flow in electromagnetic near net shape casting. J Mater Process Technol; 55: 351-359.

[19] Takemasu T, Vazquez V, Painter B, et al. Investigation of metal flow and preform optimization in flashless forging of a connecting rod. J Mater Process Technol; 59: 95-105.

[20] Mamalis AG, Szalay A, Göbl N, et al. Near net-shape manufacturing of metal sheathed superconductors by high energy rate forming techniques. Mater Sci Eng B; 53: 119-124.

[21] Okada H, Fukui Y, Sako R, et al. Numerical analysis on near net shape forming of Al-Al3Ni functionally graded material. Compos Part A Appl Sci Manuf; 34: 371-382.

[22] Kim MG, Sung SY, Lee GC, et al. Investment Casting of Near-Net Shape Gamma Titanium Aluminide Automotive Turbocharger Rotor. Mater Sci Forum; 475-479: 2547-2550.

[23] Park KS, VanTyne CJ, Moon YH. Process analysis of multistage forging by using finite element method. J Mater Process Technol; 187-188: 586-590.

[24] Yuan WX, Mei J, Samarov V, et al. Computer modelling and tooling design for near net shaped components using hot isostatic pressing. J Mater Process Technol; 182: 39-49.

[25] Chu CN, Lee JM, Kashyap RL. Skeleton-Based Design Analysis of Near Net-Shape Products. CIRP Ann - Manuf Technol; 42: 193-196.

[26] De Sam Lazaro A, Engquist DT, Edwards DB. An Intelligent Design for Manufacturability System for Sheet-metal Parts. Concurr Eng; 1: 117-123. 
[27] Caporalli Â, Gileno LA, Button ST. Expert system for hot forging design. J Mater Process Technol; 80-81: 131-135.

[28] Yin Z, Ding H, Xiong Y. Virtual prototyping of mold design: Geometric mouldability analysis for near-net-shape manufactured parts by feature recognition and geometric reasoning. CAD Comput Aided Des; 33: 137-154.

[29] Konak A, Kulturel-Konak S, Smith AE, et al. Estimation of shrinkage for near net-shape using a neural network approach. J Intell Manuf; 14: 219-228.

[30] Medellin H, Corney JR, Davies JBC, et al. Octree based production of near net shape component. IEEE Trans Autom Sci Eng; 5: 457-466.

[31] Löwer M, Beger A-L, Raza I, et al. Growing Near Net Shape Components from Renewable Materials. Procedia CIRP; 29: 609-614.

[32] Kudo H. Towards Net-Shape Forming. J Mater Process Technol; 22: 307-342.

[33] Moriguchi I. Cold forging of gears and other complex shapes. J Mater Process Technol; 35: 439-450.

[34] Siegert K, Kammerer M, Keppler-Ott T, et al. Recent developments on high precision forging of aluminum and steel. J Mater Process Technol; 71: 91-99.

[35] Yoshimura H, Tanaka K. Precision forging of aluminum and steel. J Mater Process Technol; 98: 196-204.

[36] Kruth J-P, Leu MC, Nakagawa T. Progress in Additive Manufacturing and Rapid Prototyping. CIRP Ann - Manuf Technol; 47: 525-540.

[37] Doege E, Bohnsack R. Closed die technologies for hot forging. J Mater Process Technol; 98: 165170.

[38] Dean T. The net-shape forming of gears. Mater Des; 21: 271-278.

[39] Mac Donald BJ, Hashmi MSJ. Near-net-shape manufacture of engineering components using bulgeforming processes: A review. J Mater Process Technol; 120: 341-347.

[40] Mudge RRP, Wald NNR. Laser engineered net shaping advances additive manufacturing and repair. Weld Journal-New York-; 86: 44-48.

[41] Yamamoto Y, Kiggans JO, Clark MB, et al. Consolidation Process in Near Net Shape Manufacturing of Armstrong CP-Ti/Ti-6Al-4V Powders. Key Eng Mater; 436: 103-111.

[42] Witulski T, Heussen JMM, Winkelmann A, et al. Near Net Shape Forming of Particulate Reinforced AI-AIIoys by Isothermal Forming Compared to Semi Solid Forming. J Mater Process Technol; 136: 415-420.

[43] Kang CG, Jung YJ, Youn SW. Horizontal reheating of aluminum alloys and semi-solid casting for a near net shape compressor component. J Mater Process Technol; 135: 158-171.

[44] Kapranos P, Ward P., Atkinson H., et al. Near net shaping by semi-solid metal processing. Mater Des; 21: 387-394.

[45] Yin Y De, Li SZ, Kang YL, et al. Influence of Roll Speed Schedule on Continuous Tube Rolling Process of Semi-Floating Mandrel Mill. Adv Mater Res; 148-149: 563-568.

[46] Curle U a. Semi-solid near-net shape rheocasting of heat treatable wrought aluminum alloys. Trans 
Nonferrous Met Soc China (English Ed; 20: 1719-1724.

[47] Gupta M, Ling S. Microstructure and mechanical properties of hypo/hyper-eutectic Al-Si alloys synthesized using a near-net shape forming technique. J Alloys Compd; 287: 284-294.

[48] Sung SY, Kim YJ. Economic net-shape forming of TiAl alloys for automotive parts. Intermetallics; 14: $1163-1167$.

[49] Dirba I, Sawatzki S, Gutfleisch O. Net-shape and crack-free production of Nd-Fe-B magnets by hot deformation. J Alloys Compd; 589: 301-306.

[50] Arribas M, López B, Rodriguez-Ibabe JM. Additional grain refinement in recrystallization controlled rolling of Ti-microalloyed steels processed by near-net-shape casting technology. Mater Sci Eng A; 485: 383-394.

[51] Köhl M, Habijan T, Bram M, et al. Powder metallurgical near-net-shape fabrication of porous NiTi shape memory alloys for use as long-term implants by the combination of the metal injection molding process with the space-holder technique. Adv Eng Mater; 11: 959-968.

[52] Qi H, Azer M, Ritter a. Studies of Standard Heat Treatment Effects on Microstructure and Mechanical Properties of Laser Net Shape Manufactured INCONEL 718. Metall Mater Trans A; 40: 2410-2422.

[53] Lewis GK, Milewski JO, Thoma D. Properties of Near-Net Shape Metallic Components Made by the Directed Light Fabrication Process. 513-520.

[54] Milewski J., Lewis G., Thoma D., et al. Directed light fabrication of a solid metal hemisphere using 5-axis powder deposition. J Mater Process Technol; 75: 165-172.

[55] Qi H, Azer M, Singh P. Adaptive toolpath deposition method for laser net shape manufacturing and repair of turbine compressor airfoils. Int J Adv Manuf Technol; 48: 121-131.

[56] Janney M a., Ren W, Kirby GH, et al. Gelcast Tooling: Net Shape Casting and Green Machining. Mater Manuf Process; 13: 389-403.

[57] Krishna BV, Bose S, Bandyopadhyay A. Laser Processing of Net-Shape NiTi Shape Memory Alloy. Metall Mater Trans A; 38: 1096-1103.

[58] Taminger KM, Hafley R a. Electron Beam Freeform Fabrication ( EBF 3 ) for Cost Effective NearNet Shape Manufacturing. NASA Publ 2006; NASA/TM.

[59] Hartley PJ. Production of Aluminum-Lithium Near Net Shape Extruded Cylinders. Hampton,Virginia (USA): National Aeronautics and Space Administratio (NASA). 25.

[60] Hinz D, Kirchner a., Brown DN, et al. Near net shape production of radially oriented NdFeB ring magnets by backward extrusion. J Mater Process Technol; 135: 358-365.

[61] Shi K, Shan DB, Xu WC, et al. Near net shape forming process of a titanium alloy impeller. J Mater Process Technol; 187-188: 582-585.

[62] Julien B, Després M. Metal Injection Moulding: A Near Net Shape Fabrication Method for the Manufacture of Turbine Engine Component. In: Cost Effective Manufacture via Net-Shape Processing. 2006, pp. 8-1-8-16.

[63] Liang X, Pan F, Zhou S, et al. Edge containment of a twin-roll caster for near net shape strip casting. J Mater Process Technol; 63: 788-791. 
[64] Bewlay BP, Gigliotti MFX, Hardwicke CU, et al. Net-shape manufacturing of aircraft engine disks by roll forming and hot die forging. J Mater Process Technol; 135: 324-329.

[65] Park JW, Lee JG, Jun CS. Near net-shape five-axis face milling of marine propellers. Int J Precis Eng Manuf; 10: 5-12.

[66] Onodera S, Sawai K. Current cold-forging techniques for the manufacture of complex precision nearnet-shapes. J Mater Process Technol; 35: 385-396.

[67] Maegaard V. Cold forging of net or near-net shape components. J Mater Process Technol; 35: 429438.

[68] Hirt G, Cremer R, Witulski T, et al. Lightweight near net shape components produced by thixoforming. Mater Des; 18: 315-321.

[69] Schlienger E, Dimos D, Griffith M, et al. Near net shape production of metal components using LENS. Proc Third Pacific Rim Int Conf Adv Mater Process Vol I, Honolulu, Hawaii, USA, July; 12: 16.

[70] Milewski JO, Lewis GK, Fonseca J, et al. Laser Powder Deposition of a Near Net Shape Injection Mold Core - A Case Study. Mater Manuf Process; 15: 247-258.

[71] Lewis GK, Schlienger E. Practical considerations and capabilities for laser assisted direct metal deposition. Mater Des; 21: 417-423.

[72] Bak D. Rapid prototyping or rapid production? 3D printing processes move industry towards the latter. Assem Autom; 23: 340-345.

[73] Blackwell PL, Wisbey a. Laser-aided manufacturing technologies; their application to the near-net shape forming of a high-strength titanium alloy. J Mater Process Technol; 170: 268-276.

[74] Kottman M, Zhang S, McGuffin-Cawley J, et al. Laser Hot Wire Process: A Novel Process for NearNet Shape Fabrication for High-Throughput Applications. Jom; 67: 622-628.

[75] LaSalle JC, Zedalis M. Net-shape processing using an aqueous-based MIM binder. Jom; 51: 38-39.

[76] Groenbaek J, Birker T. Innovations in cold forging die design. J Mater Process Technol; 98: 155161.

[77] Dahlman P, Escursell M. High-pressure jet-assisted cooling: A new possibility for near net shape turning of decarburized steel. Int J Mach Tools Manuf; 44: 109-115.

[78] Douglas R, Kuhlmann D. Guidelines for precision hot forging with applications. J Mater Process Technol; 98: 182-188.

[79] Cai J, Dean T a., Hu ZM. Alternative die designs in net-shape forging of gears. J Mater Process Technol; 150: 48-55.

[80] Klug KL, Ucok I, Gungor MN, et al. The near-net-shape manufacturing of affordable titanium components for the M777 lightweight howitzer. Jom; 56: 35-41.

[81] Behrens B a., Doege E, Reinsch S, et al. Precision forging processes for high-duty automotive components. J Mater Process Technol; 185: 139-146.

[82] Viloti D, Plan M, Kuzman K, et al. APPLICATION OF NET SHAPE AND NEAR-NET SHAPE FORMING TECHNOLOGIES IN MANUFACTURE OF ROLLER BEARING COMPONENTS AND CARDAN SHAFTS. $J$ Technol Plast; 32: 88-103. 
[83] Cominotti R, Gentili E. Near net shape technology: An innovative opportunity for the automotive industry. Robot Comput Integr Manuf; 24: 722-727.

[84] Tateno M. Development of Large Size High Quality Steels and Their Future Prospect as 'Near Net Shape' Material. Trans ISIJI; 25: 97-108.

[85] Bhatkal RM, Hannibal T. The technical cost modeling of near net-shape P M manufacturing. JomJournal Miner Met Mater Soc; 51: 26-27.

[86] Campbell J. The concept of net shape for castings. Mater Des; 21: 373-380. 